Article

\title{
Unusual Emission of Polystyrene-Based Alternating Copolymers Incorporating Aminobutyl Maleimide Fluorophore-Containing Polyhedral Oligomeric Silsesquioxane Nanoparticles
}

\author{
Mohamed Gamal Mohamed ${ }^{1}$, Yu-Ru Jheng ${ }^{1}$, Shu-Ling Yeh ${ }^{2}$, Tao Chen ${ }^{3}$ \\ and Shiao-Wei Kuo 1,3,4,* \\ 1 Department of Materials and Optoelectronic Science, National Sun Yat-Sen University, Kaohsiung 80424, \\ Taiwan; mgamal.eldin12@yahoo.com (M.G.M.); m043100015@student.nsysu.edu.tw (Y.-R.J.) \\ 2 Department of Applied Chemistry, National Chiao Tung University, Hsinchu 300, Taiwan; \\ ShuLingYeh@itri.org.tw \\ 3 Ningbo Institute of Material Technology and Engineering, Key Laboratory of Graphene Technologies and \\ Applications of Zhejiang Province, Chinese Academy of Science, Zhongguan West Road 1219, \\ Ningbo 315201, China; tao.chen@nimte.ac.cn \\ 4 Department of Medicinal and Applied Chemistry, Kaohsiung Medical University, Kaohsiung 807, Taiwan \\ * Correspondence: kuosw@faculty.nsysu.edu.tw
}

Academic Editor: Po-Chih Yang

Received: 30 November 2016; Accepted: 13 March 2017; Published: 15 March 2017

\begin{abstract}
In this study, we synthesized an unusual 2-aminobutyl maleimide isobutyl polyhedral oligomeric silsesquioxane (MIPOSS-NHBu) monomer lacking conventional fluorescent groups. We then prepared poly(styrene-alt-2-aminobutyl maleimide isobutyl POSS) [poly(S-alt-MIPOSS-NHBu)] and poly(4-acetoxystyrene-alt-2-aminobutyl maleimide isobutyl POSS) [poly(AS-alt-MIPOSS-NHBu)] copolymers through facile free radical copolymerizations using azobisisobutyronitrile as the initiator and tetrahydrofuran as the solvent. A poly(4-hydroxystyrene-alt-2-aminobutyl maleimide isobutyl POSS) [poly(HS-alt-MIPOSS-NHBu)] copolymer was prepared through acetoxyl hydrazinolysis of poly(AS-alt-MIPOSS-NHBu). We employed ${ }^{1} \mathrm{H},{ }^{13} \mathrm{C}$, and ${ }^{29} \mathrm{Si}$ nuclear magnetic resonance spectroscopy; Fourier transform infrared spectroscopy; differential scanning calorimetry; and photoluminescence spectroscopy to investigate the structures and the thermal and optical properties of the monomers and novel POSS-containing alternating copolymers. Intramolecular hydrogen bonding between the amino and dihydrofuran-2,5-dione group and clustering of the locked $\mathrm{C}=\mathrm{O}$ groups from the POSS nanoparticles in the MIPOSS-NHBu units restricted the intramolecular motion of the polymer chain, causing it to exhibit strong light emission. As a result, the MIPOSS-NHBu monomer and the poly(AS-alt-MIPOSS-NHBu) copolymer both have potential applicability in the detection of metal ions with good selectivity.
\end{abstract}

Keywords: unusual emission; POSS; hydrogen bonding; alternative copolymer

\section{Introduction}

In recent years, fluorescent materials and polymers have attracted much attention in academic and industrial fields for their potential applications in optoelectronic devices, organic light emitting diodes, bio-imaging, chemical sensors, biosensors, drug delivery, DNA probing, and protein sensors [1-11]. Most fluorescent organic molecules exhibit a strong emission in dilute solution, but become non-luminescent or weakly emissive in their condensed or aggregated state, a phenomenon known as aggregation-caused quenching [12-15]. Therefore, synthesized organic luminescent 
materials and polymers that exhibit strong fluorescence in the solid state have industrial and research applications [16-18]. In 2001, Tang and co-workers discovered novel silole derivatives that are highly emissive in the aggregated state and non-emissive in solution. These materials display aggregation-induced emission (AIE) or aggregation-induced enhancement emission (AIEE) [19-22]. Many reports have suggested ways to enhance the intense fluorescence of organic materials in the solid state, including J-aggregate formation [23], constructing cross-linked polymer networks and dendrimers [24], introducing non-planar structures and bulky substituents [25], restricting intramolecular motions (for AIE mechanism) [26], and inducing excited state intramolecular proton transfer $[27,28]$ and twisted intramolecular charge transfer $[29,30]$.

Several fluorescent polymers lacking benzene or heterocyclic rings have been developed because for their potential for excellent biocompatibility and biodegradability [31-33]. For instance, Yang and co-workers noted the unexpected strong emission from monomers and polymers containing 2-thio- and 2-amino-succinimide, caused by the isolation effect [34]. Pucci et al. reported the unexpected fluorescence of polyisobutene-grafted succinic anhydride and imide, ascribed to the aggregation of non-emissive chromophoric $\mathrm{C}=\mathrm{O}$ groups and intermolecular interactions among the dihydrofuran-2,5-dione groups [35]. Zhao et al. synthesized pure oxygenic nonconjugated poly[(maleic anhydride-alt-(vinyl acetate)] through free-radical polymerization; this alternating copolymer exhibited strong light emission and a solvatochromic effect with electron-rich solvents, with the emission behavior originating from the clustering of locked $\mathrm{C}=\mathrm{O}$ groups [36]. Wu et al. reported the first water-soluble maleimide carrying an $\mathrm{NIR}-\mathrm{BF}_{2}$-azadipyrromethene (NIR-AZA) as near infrared fluorochrome and this fluorochrome reacted rapidly with biomolecules [37]. Recently, we prepared polystyrene-based alternating copolymers containing maleimide polyhedral oligomeric silsesquioxane (MIPOSS) nanoparticles (NPs) and found that the poly(MIPOSS) homopolymer had greater photoluminescence emission than the POSS-containing alternating copolymers, due to the high crystallinity and the clustering of locked $\mathrm{C}=\mathrm{O}$ groups of the MIPOSS segments restricting intramolecular motion of the polymer chains [31].

Inorganic/organic hybrid materials and polymers containing POSS units and their derivatives have attracted great attention from research and industrial areas because of the unique properties resulting from the well-defined three-dimensional cubic cages having dimensions of 1-3 nm. The chemical formula of a typical POSS structure is $\left(\mathrm{RSiO}_{1.5}\right)_{8}$; it presents organic functional groups (R) that can be reactive or non-reactive as the outer layer, with an inner core of an inorganic cage structure comprising silicon and oxygen atoms [38-42]. POSS NPs can be classified into three main types: molecular silica and mono- and multifunctional POSS NPs. The incorporation of POSS NPs into a polymeric matrix has been performed through living/controlled polymerization and click chemistry to prepare novel hybrid materials exhibiting good heat-resistance, flammability, and thermal and mechanical properties, and low dielectric constants [43-50]. The self-assembly of POSS-containing hybrid polymers has also been studied. For example, Cheng et al. reported the various morphologies of a giant surfactant (PS-APOSS), from vesicles to wormlike structures to spherical micelles in selective solvents [51]. Zhang et al. investigated the self-assembly of POSS-containing poly(ethylene oxide)s (POSS-PEO) and poly(acrylic acid)s (POSS-PAA) in aqueous solution; they observed that these POSS-containing hybrid polymers formed aggregates having various structures [52]. We have synthesized POSS-containing helical polypeptide copolymers through controlled ring-opening polymerizations of $\gamma$-benzyl-L-glutamate $N$-carboxyanhydride (BLG-NCA) using aminopropyl isobutyl POSS as the initiator; these hybrid polypeptides formed self-assembled nanoribbon structures in toluene [53]. Hayakawa et al. studied the microphase-separated structures of poly(styrene- $b$-methacrylate POSS) diblock copolymers, synthesized through anionic living polymerizations with well-defined molecular distributions [54,55]. Recently, Zhang et al. demonstrated that the incorporation of MIPOSS NPs could improve the thermal properties of poly(S-alt-MIPOSS) alternating copolymers [56]. 
In the present study, we synthesized maleimide/succinimide isobutyl POSS derivatives containing alkyl groups (Scheme 1). We then used 2-bromomaleimide and 2-aminomaleimide isobutyl POSS as raw materials to prepare several POSS-containing alternating copolymers-poly(S-alt-MIPOSS-Br), poly(S-alt-MIPOSS-NHBu), poly(AS-alt-MIPOSS-Br), and poly(AS-alt-MIPOSS-NHBu)—through simple free radical copolymerizations using azobisisobutyronitrile (AIBN) as the initiator in dry tetrahydrofuran (THF).

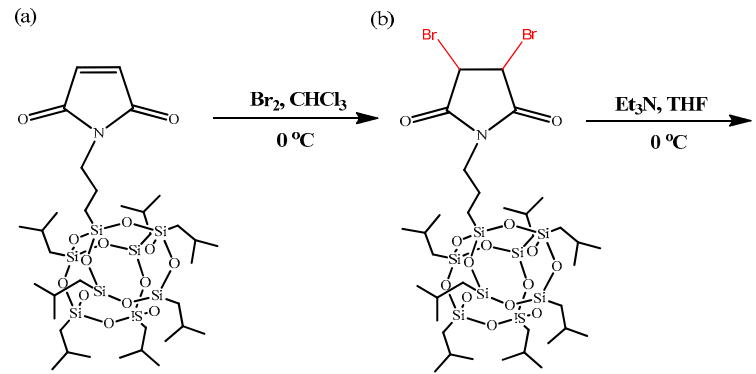

Scheme 1. Chemical structures and synthesis of: and (d) MIPOSS-NHBu. (c)

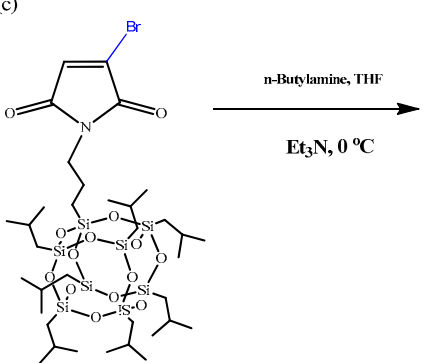

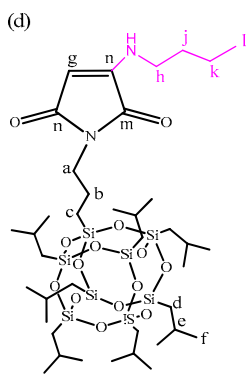

Subsequently, we prepared a poly(HS-alt-MIPOSS-NHBu) alternating copolymer through acetoxyl hydrazinolysis of poly(AS-alt-MIPOSS-NHBu) in the presence of hydrazine monohydrate in 1,4-dioxane at room temperature (Scheme 2). We used ${ }^{1} \mathrm{H}-,{ }^{13} \mathrm{C}-$, and ${ }^{29} \mathrm{Si}-\mathrm{NMR}$ spectroscopy and Fourier transform infrared (FTIR) spectroscopy to confirm the structures of the monomers and polymers. Furthermore, we used differential scanning calorimetry (DSC) and thermogravimetric analysis (TGA) to examine the glass transition temperatures, thermal degradation temperatures, and char yields of the POSS-containing alternating copolymers. In addition, we used wide-angle X-ray diffraction (WAXD) and photoluminescence (PL) spectroscopy to determine the crystallinity and optical properties of these monomers and POSS-containing alternating polymers. PL spectroscopy also revealed the potential applications of MIPOSS-NHBu and poly(AS-alt-MIPOSS-NHBu) as sensors for metal ions in solution.

(a)

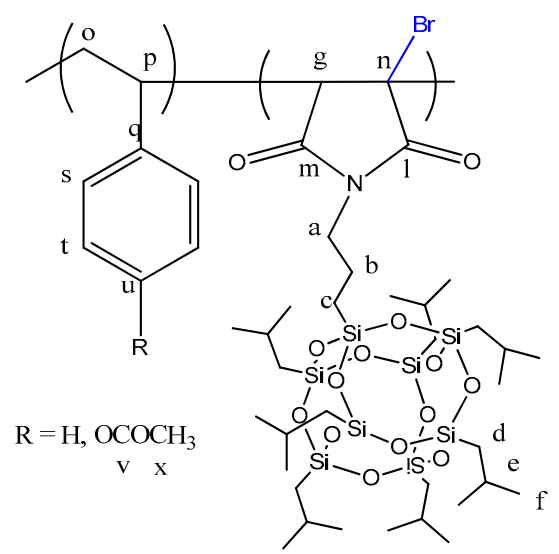

(b)
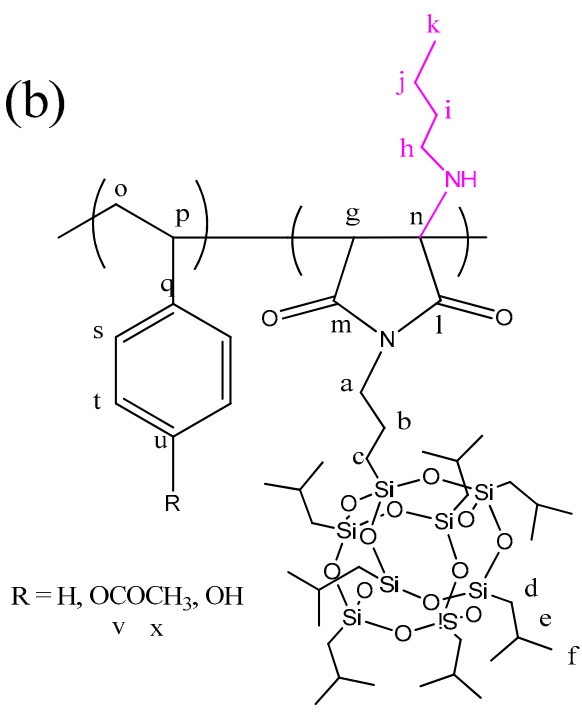

Scheme 2. Chemical structures of: (a) poly(styrene-based-alt-MIPOSS-Br); and (b) poly(styrene-basedalt-MIPOSS-NHBu) copolymers. 


\section{Experimental Section}

\subsection{Materials}

Methanol $(\mathrm{MeOH})$, n-butylamine, chloroform $\left(\mathrm{CHCl}_{3}\right)$, dichloromethane (DCM), hexane, ethyl acetate (EA), tetrahydrofuran (THF), bromine $\left(\mathrm{Br}_{2}\right)$, anhydrous magnesium sulfate $\left(\mathrm{MgSO}_{4}\right)$, sodium chloride $(\mathrm{NaCl})$, triethylamine $\left(\mathrm{Et}_{3} \mathrm{~N}\right)$, and hydrazine monohydrate $\left(\mathrm{N}_{2} \mathrm{H}_{4} \cdot \mathrm{H}_{2} \mathrm{O}\right)$ were purchased from Alfa-Aesar. Maleimide isobutyl POSS (MIPOSS) NPs was obtained from Hybrid Plastics and used without the purification. AIBN was purchased from Sigma-Aldrich (St. Louis, MO, USA), recrystallized from $\mathrm{MeOH}$ three times, and stored in a refrigerator to avoid decomposition. Styrene and 4-acetoxystyrene were also received from Sigma-Aldrich. Prior to free radical copolymerization, these monomers were passed through an aluminum oxide column to remove any inhibitor and then dried over $\mathrm{CaH}_{2}$ overnight under a $\mathrm{N}_{2}$ atmosphere. Zinc acetate dihydrate $\left[\mathrm{Zn}\left(\mathrm{CH}_{3} \mathrm{COO}\right)_{2} \cdot 2 \mathrm{H}_{2} \mathrm{O}\right]$, iron(III) nitrate nonahydrate $\left[\mathrm{Fe}\left(\mathrm{NO}_{3}\right)_{3} \cdot 9 \mathrm{H}_{2} \mathrm{O}\right]$, iron(III) chloride $\left(\mathrm{FeCl}_{3}\right)$, aluminum nitrate nonahydrate $\left[\mathrm{Al}\left(\mathrm{NO}_{3}\right)_{3} \cdot 9 \mathrm{H}_{2} \mathrm{O}\right]$, and indium(III) chloride $\left(\mathrm{InCl}_{3}\right)$ were purchased from Alfa-Aesar (Ward Hill, MA, USA). The poly(MIPOSS) homopolymer and the poly(S-alt-MIPOSS-Br) and poly(AS-alt-MIPOSS-Br) alternating copolymers were synthesized through free radical polymerizations according to a previous report [31].

2,3-Dibromosuccinimide Isobutyl POSS (MIPOSS-2Br) [57]. $\mathrm{Br}_{2}$ solution (0.65 g, $4.01 \mathrm{mmol}$ ) diluted in $\mathrm{CHCl}_{3}(5 \mathrm{~mL})$ was added dropwise to a solution of maleimide isobutyl POSS (MIPOSS; $3.00 \mathrm{~g}$, $3.15 \mathrm{mmol})$ in dry $\mathrm{CHCl}_{3}(20 \mathrm{~mL})$ in an ice-bath under a $\mathrm{N}_{2}$ atmosphere. The mixture was then stirred for $24 \mathrm{~h}$ at room temperature. The solvent was evaporated under vacuum and the solid residue was extracted with DCM three times. The product was purified through column chromatography $\left[\mathrm{SiO}_{2}\right.$; hexane/EA, 1:1 (v/v)] to obtain a white powder. ${ }^{1} \mathrm{H}-\mathrm{NMR}\left(500 \mathrm{MHz}, \mathrm{CDCl}_{3}, \delta, \mathrm{ppm}\right)$ (Figure S1): $3.54\left(\mathrm{NCH}_{2} \mathrm{CH}_{2}\right), 1.85\left[\mathrm{CH}\left(\mathrm{CH}_{3}\right)_{2}\right], 1.68\left(\mathrm{NCH}_{2} \mathbf{C H}_{2}\right), 0.97\left[\mathrm{CH}\left(\mathbf{C H}_{3}\right)_{2}\right], 0.87\left(\mathrm{SiCH}_{2} \mathrm{CH}_{2} \mathrm{CH}_{2}\right)$, $0.61\left[\mathrm{SiCH}_{2} \mathrm{CH}\left(\mathrm{CH}_{3}\right)_{2}\right] .{ }^{13} \mathrm{C}-\mathrm{NMR}\left(125 \mathrm{MHz}, \mathrm{CDCl}_{3}, \delta, \mathrm{ppm}\right.$ ) (Figure S2): 177.58 (maleimide $\mathrm{C}=\mathrm{O}$ ), 41.6, 32.2, 29.3, 26.0, 25.7, 21.4, 9.4. FTIR $\left(\mathrm{KBr}, \mathrm{cm}^{-1}\right)$ : 1778 (asymmetric imide $\mathrm{C}=\mathrm{O}$ stretching), 1710 (symmetric imide $\mathrm{C}=\mathrm{O}$ stretching), 2947-2888 (isobutyl $\mathrm{CH}$ stretch), 1226 ( $\mathrm{CN}$ bending vibration), 1109 ( $\mathrm{Si}-\mathrm{O}-\mathrm{Si}$ stretching of POSS core).

2-Bromomaleimide Isobutyl POSS (MIPOSS-Br) [57]. $\mathrm{Et}_{3} \mathrm{~N}(0.150 \mathrm{~g}, 1.43 \mathrm{mmol})$ was added dropwise over $20 \mathrm{~min}$ to a solution of MIPOSS-2Br $(1.50 \mathrm{~g}, 1.35 \mathrm{mmol})$ in dry THF $(20 \mathrm{~mL})$ in an ice bath under a $\mathrm{N}_{2}$ atmosphere. The mixture was then stirred for $72 \mathrm{~h}$. The precipitate was filtered off and the solution concentrated (rotary evaporator) to afford a yellow solid. The crude product was purified through column chromatography (hexane:EA, 1:1) to obtain a yellow powder. ${ }^{1} \mathrm{H}-\mathrm{NMR}(500 \mathrm{MHz}$, $\left.\mathrm{CDCl}_{3}, \delta, \mathrm{ppm}\right): 6.69(\mathrm{CH}=\mathrm{C}), 3.54\left(\mathrm{NCH}_{2} \mathrm{CH}_{2}\right), 1.85\left[\mathrm{CH}\left(\mathrm{CH}_{3}\right)_{2}\right], 1.68\left(\mathrm{NCH}_{2} \mathrm{CH}_{2}\right), 0.97\left[\mathrm{CH}\left(\mathrm{CH}_{3}\right)_{2}\right]$, $0.87\left(\mathrm{SiCH}_{2} \mathrm{CH}_{2} \mathrm{CH}_{2}\right), 0.61\left[\mathrm{SiCH}_{2} \mathrm{CH}\left(\mathrm{CH}_{3}\right)_{2}\right] .{ }^{13} \mathrm{C}-\mathrm{NMR}\left(125 \mathrm{MHz}, \mathrm{CDCl}_{3}, \delta, \mathrm{ppm}\right): 169.03,166.72$ (maleimide $\mathrm{C}=\mathrm{O}), 134.67,132.36,46.31,41.38,38.44,31.90,9.01$. FTIR $\left(\mathrm{KBr}, \mathrm{cm}^{-1}\right)$ : 1768 (asymmetric imide $\mathrm{C}=\mathrm{O}$ stretching), 1714 (symmetric imide $\mathrm{C}=\mathrm{O}$ stretching), 1636 ( $\mathrm{C}=\mathrm{C}$ stretch), 2946-2887 (isobutyl $\mathrm{CH}$ stretch), 1238 (C-N bending vibration), 1109 ( $\mathrm{Si}-\mathrm{O}-\mathrm{Si}$ stretching of POSS core).

2-(Butylamino)-Maleimide Isobutyl POSS (MIPOSS-NHBu). n-Butylamine $(0.037 \mathrm{~g}, 0.50 \mathrm{mmol})$ was added to a solution of MIPOSS-Br $(0.500 \mathrm{~g}, 0.484 \mathrm{mmol})$ in dry THF $(20 \mathrm{~mL})$ in an ice bath and then the mixture was stirred for $10 \mathrm{~min}$. $\mathrm{Et}_{3} \mathrm{~N}(0.052 \mathrm{~g}, 0.51 \mathrm{mmol})$ was added dropwise to the cooled reaction mixture (ice bath) and then the mixture was stirred for $24 \mathrm{~h}$ at room temperature. The solvent was evaporated under vacuum and the solid residue was extracted three times in with DCM $(40 \mathrm{~mL})$, water $(20 \mathrm{~mL})$, and aqueous $\mathrm{NaCl}(30 \mathrm{~mL})$ and then dried over $\mathrm{MgSO}_{4}$. The crude mixture was purified through column chromatography $\left(\mathrm{SiO}_{2}\right.$; hexane/EA, 1:1) to yield a yellow powder. ${ }^{1} \mathrm{H}-\mathrm{NMR}$ $\left(500 \mathrm{MHz}, \mathrm{CDCl}_{3}, \delta, \mathrm{ppm}\right)$ (Figure 1): $6.69(\mathrm{CH}=\mathrm{C}), 3.54\left(\mathrm{NCH}_{2} \mathrm{CH}_{2}\right), 3.95\left(\mathrm{NH}-\mathrm{CH}_{2} \mathrm{CH}_{2}\right)$, $1.85\left[\mathrm{CH}\left(\mathrm{CH}_{3}\right)_{2}\right], 1.68\left(\mathrm{NCH}_{2} \mathbf{C H}_{2}\right), 1.28\left(\mathrm{NHCH}_{2} \mathbf{C H}_{2}\right), 1.08\left(\mathrm{CH}_{2} \mathrm{CH}_{2} \mathrm{CH}_{2} \mathrm{CH}_{3}\right), 0.97\left[\mathrm{CH}\left(\mathrm{CH}_{3}\right)_{2}\right]$ and $\left[\mathrm{NH}\left(\mathrm{CH}_{2}\right)_{3} \mathrm{CH}_{3}\right], 0.87\left(\mathrm{SiCH}_{2} \mathrm{CH}_{2} \mathrm{CH}_{2}\right), 0.61\left[\mathrm{SiCH}_{2} \mathrm{CH}\left(\mathrm{CH}_{3}\right)_{2}\right] .{ }^{13} \mathrm{C}-\mathrm{NMR}\left(125 \mathrm{MHz}, \mathrm{CDCl}_{3}\right.$, $\delta$, ppm) (Figure 2): 169.03, 166.72 (maleimide $\mathrm{C}=\mathrm{O}$ ), 134.67, 132.36, 46.31, 41.38, 38.44, 36.17, 20.45, 
31.90, 14.58, 9.01. FTIR ( $\mathrm{KBr}, \mathrm{cm}^{-1}$ ) (Figure 3): 3444 ( $\mathrm{NH}$ stretch), 1768 (asymmetric imide $\mathrm{C}=\mathrm{O}$ stretching), 1714 (symmetric imide $\mathrm{C}=\mathrm{O}$ stretching), 1636 ( $\mathrm{C}=\mathrm{C}$ stretch), 2946-2887 (isobutyl $\mathrm{CH}$ stretch), 1238 (C-N bending vibration), 1109 ( $\mathrm{Si}-\mathrm{O}-\mathrm{Si}$ stretching of POSS core).

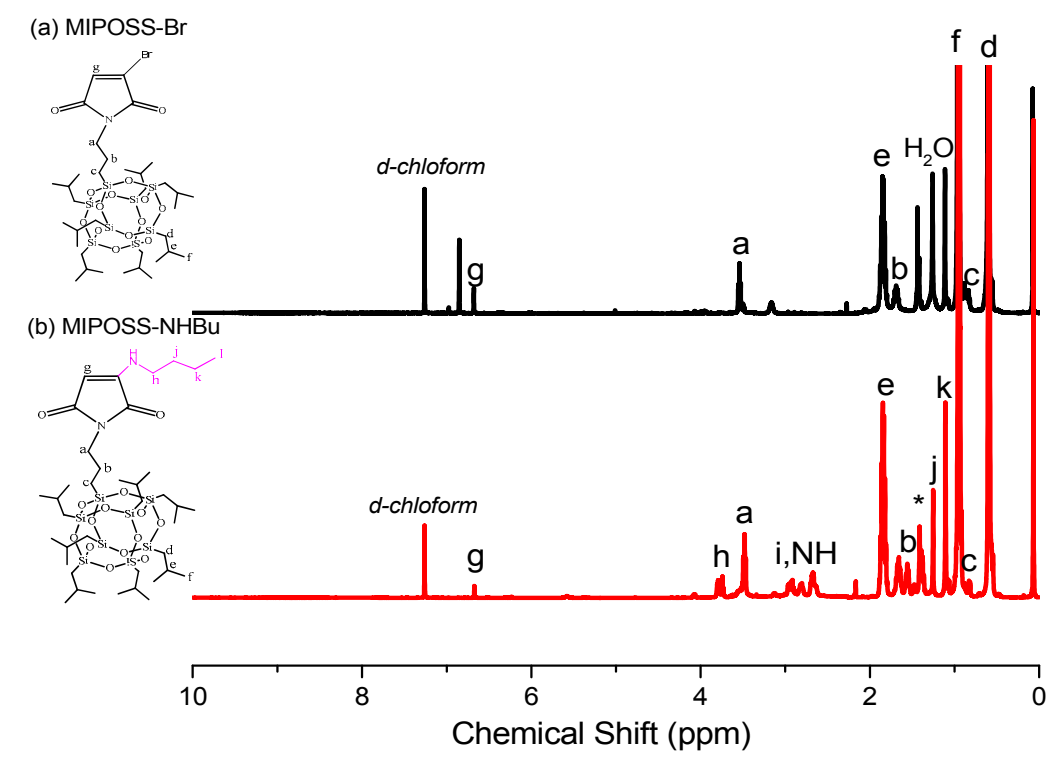

Figure 1. ${ }^{1} \mathrm{H}-\mathrm{NMR}$ spectra of the monomers (a) MIPOSS-Br and (b) MIPOSS-NHBu.

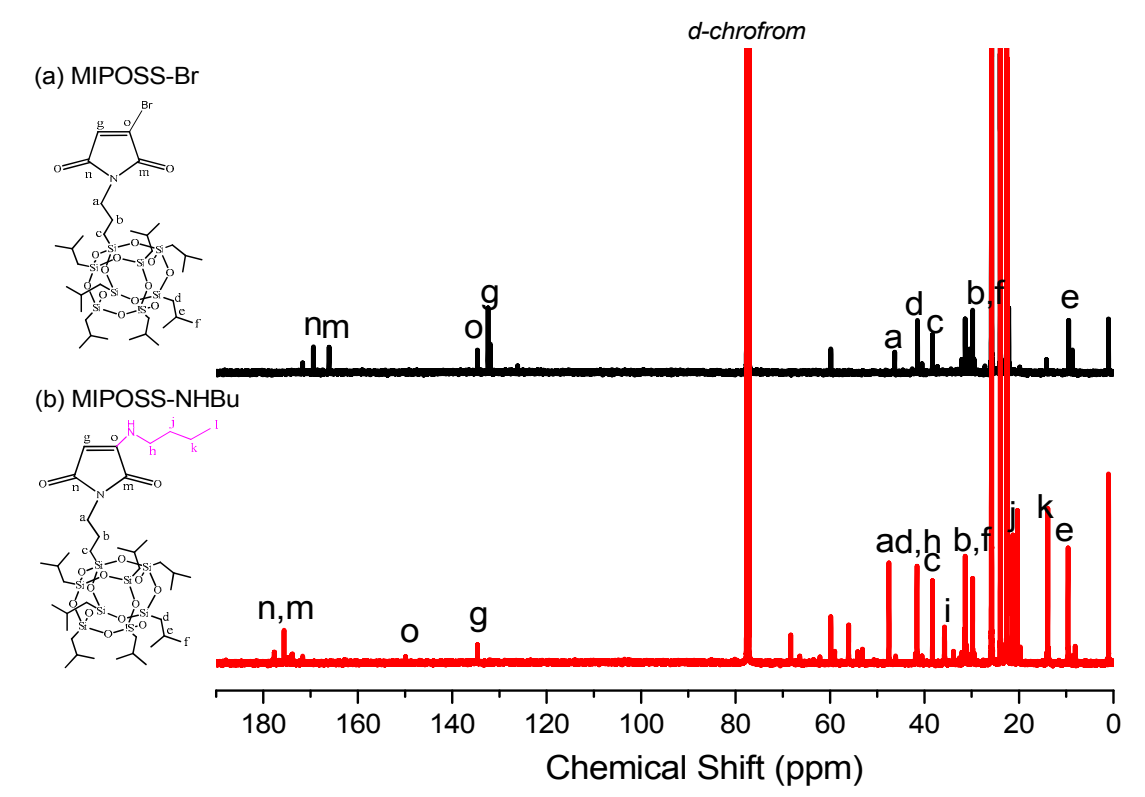

Figure 2. ${ }^{13} \mathrm{C}-\mathrm{NMR}$ spectra of the monomers: (a) MIPOSS-Br; and (b) MIPOSS-NHBu.

Poly(S-alt-MIPOSS-Br), Poly(S-alt-MIPOSS-NHBu), and Poly(AS-alt-MIPOSS-NHBu) Alternating Copolymers. A solution of MIPOSS-Br $(0.50 \mathrm{~g}, 0.50 \mathrm{mmol})$ or MIPOSS-NHBu $(0.40 \mathrm{~g}, 0.077 \mathrm{mmol})$, styrene $(0.33 \mathrm{~g}, 3.16 \mathrm{mmol})$ or 4-acetoxystyrene $(0.52 \mathrm{~g}, 3.17 \mathrm{mmol})$, and AIBN ( $5 \mathrm{wt} \%)$ were dissolved in dry THF $(60 \mathrm{~mL})$ was heated at $70-80{ }^{\circ} \mathrm{C}$ for $24 \mathrm{~h}$. The copolymerization was quenched through cooling the flask in an ice bath and exposing the contents to air for $1 \mathrm{~h}$. The crude polymer was precipitated upon pouring the reaction solution into a large amount of cold $\mathrm{MeOH}$. The crude polymer was reprecipitated from cold THF/MeOH many times to remove any unreacted MIPOSS-Br or MIPOSS-NH and $\mathrm{S}$ or AS monomer. The alternating copolymers were dried at $50^{\circ} \mathrm{C}$ under high vacuum overnight 
to remove any residual solvent. For poly(S-alt-MIPOSS-Br): ${ }^{1} \mathrm{H}-\mathrm{NMR}\left(500 \mathrm{MHz}, \mathrm{CDCl}_{3}, \delta, \mathrm{ppm}\right)$ : 7.04 (ArH in polystyrene backbone), 3.40 (polymer backbone and $\mathrm{NCH}_{2} \mathrm{CH}_{2}$ ), $1.85\left[\mathrm{CH}\left(\mathrm{CH}_{3}\right)_{2}\right]$, $1.60\left(\mathrm{SiCH}_{2} \mathrm{CH}_{2}\right), 0.96\left[\mathrm{CH}\left(\mathrm{CH}_{3}\right)_{2}\right], 0.60\left(\mathrm{SiCH}_{2}\right) .{ }^{13} \mathrm{C}-\mathrm{NMR}\left(125 \mathrm{MHz}, \mathrm{CDCl}_{3}, \delta, \mathrm{ppm}\right): 178.4$ (maleimide $\mathrm{C}=\mathrm{O}$ ), 169.7, 151.3, 130.6, 122.7, 41.7, 30.1, 9.9. FTIR $\left(\mathrm{KBr}, \mathrm{cm}^{-1}\right)$ : 1773 (asymmetric $\mathrm{C}=\mathrm{O}$ stretching, imide and $\mathrm{C}=\mathrm{O}, \mathrm{OCOCH}_{3}$ group), 1706 (symmetric imide $\mathrm{C}=\mathrm{O}$ stretching), $1226(\mathrm{C}-\mathrm{N}$ bending), 1109 (Si-O-Si stretching of POSS core). For poly(S-alt-MIPOSS-NHBu): ${ }^{1} \mathrm{H}-\mathrm{NMR}(500 \mathrm{MHz}$, $\mathrm{CDCl}_{3}, \delta, \mathrm{ppm}$ ): 7.04-6.57 (ArH in polystyrene backbone), 3.40 (polymer backbone and $\mathrm{NCH}_{2} \mathrm{CH}_{2}$ ), $2.50\left(\mathrm{NCH}_{2} \mathrm{CH}_{2}\right), 2.12\left(\mathrm{NCH}_{2} \mathrm{CH}_{2}\right), 1.85\left[\mathrm{CH}\left(\mathrm{CH}_{3}\right)_{2}\right], 1.60\left(\mathrm{SiCH}_{2} \mathrm{CH}_{2}\right), 1.13\left(\mathrm{NCH}_{2} \mathrm{CH}_{2} \mathrm{CH}_{2}\right)$, $0.96\left[\mathrm{CH}\left(\mathrm{CH}_{3}\right)_{2}\right]$ and $\left(\mathrm{CH}_{3} \mathrm{CH}_{2}\right), 0.60\left(\mathrm{SiCH}_{2}\right) .{ }^{13} \mathrm{C}-\mathrm{NMR}\left(125 \mathrm{MHz}, \mathrm{CDCl}_{3}, \delta, \mathrm{ppm}\right): 171.32$ (maleimide $\mathrm{C}=\mathrm{O}), 128.6$, 128.0, 126.2, 41.6, 32.2, 31.8, 29.3, 26.0, 25.7, 22.2, 21.4, 9.4. FTIR $\left(\mathrm{KBr}, \mathrm{cm}^{-1}\right): 1773$ (asymmetric $\mathrm{C}=\mathrm{O}$ stretching, imide and $\mathrm{C}=\mathrm{O}, \mathrm{OCOCH}_{3}$ group), 1706 (symmetric imide $\mathrm{C}=\mathrm{O}$ stretching), 1226 (CN bending), 1109 (Si-O-Si stretching of POSS core). For poly(AS-alt-MIPOSS-NHBu), most of the signals in the ${ }^{1} \mathrm{H}$ and ${ }^{13} \mathrm{C}-\mathrm{NMR}$ spectra were the same as those for poly(S-alt-MIPOSS-NHBu), with the following exceptions: ${ }^{1} \mathrm{H}-\mathrm{NMR}, 6.85-6.51$ ( $\mathrm{ArH}$ in polystyrene backbone), $2.26\left(\mathrm{OCOCH}_{3}\right)$; ${ }^{13} \mathrm{C}-\mathrm{NMR}, 179.1$ (C=O imide), 170.1 ( $\mathrm{C}=\mathrm{O}$ acetate), $29.77 \mathrm{ppm}\left(\mathbf{C H}_{3}\right)$.

Poly(HS-alt-MIPOSS-NHBu) Alternating Copolymer. Hydrazine monohydrate ( $15.5 \mathrm{~g}, 3.10 \mathrm{mmol})$ was added dropwise over $1 \mathrm{~h}$ to a solution of poly(AS-alt-MIPOSS-NHBu) $(0.50 \mathrm{~g})$ in 1,4-dioxane $(25 \mathrm{~mL})$ in an ice bath. The mixture was then stirred at room temperature overnight. The solvent was evaporated under vacuum and the solid residue was dissolved in DCM $(50 \mathrm{~mL})$ and extracted with water to remove any excess hydrazine monohydrate. The combined organic phases were dried $\left(\mathrm{MgSO}_{4}\right)$ for $1 \mathrm{~h}$ and then concentrated (rotary evaporator) to give a white powder. ${ }^{1} \mathrm{H}-\mathrm{NMR}\left(500 \mathrm{MHz}, \mathrm{CDCl}_{3}\right.$, $\delta, \mathrm{ppm}): 8.98(\mathrm{OH}), 7.05-6.46$ (ArH in polystyrene backbone). ${ }^{13} \mathrm{C}-\mathrm{NMR}\left(125 \mathrm{MHz}, \mathrm{CDCl}_{3}, \delta, \mathrm{ppm}\right)$ : 179.42 (maleimide $\mathrm{C}=\mathrm{O}$ ), 155.86, 128.64, 114.84, 41.62, 32.21, 29.34, 26.07, 25.73, 22.20, 21.39, 9.45. FTIR $\left(\mathrm{KBr}, \mathrm{cm}^{-1}\right)$ : 3380 ( $\mathrm{OH}$ stretching), 2948-2888 (isobutyl group), 1776 (asymmetric $\mathrm{C}=\mathrm{O}$, imide), 1706 (symmetric $\mathrm{C}=\mathrm{O}$ stretching, imide), 1226 (C-N bending), 1109 ( $\mathrm{Si}-\mathrm{O}-\mathrm{Si}$ stretching of POSS core). Table 1 summarizes the number-average molecular weight $\left(M_{n}\right)$, the molecular weight distribution, and the thermal properties of these alternating copolymers.

\subsection{Characterization}

${ }^{1} \mathrm{H}$ - and ${ }^{13} \mathrm{C}-\mathrm{NMR}$ spectra were recorded using an INOVA 500 spectrometer (McKinley Scientific, Sparta, NJ, USA), $\mathrm{CDCl}_{3}$ as the solvent, and tetramethylsilane (TMS) as the internal reference. A Bruker Tensor-27 FTIR spectrometer (Billerica, MA, USA) was used to quantitatively characterize the chemical structures of the alternating copolymers, which were cast from THF solutions onto $\mathrm{KBr}$ crystal plates. The spectra were collected from 32 scans at a resolution of $4 \mathrm{~cm}^{-1}$ at room temperature. The molecular weights and polydispersities of the synthesized alternating copolymers were determined using a Waters 510 gel permeation chromatography (GPC, Waters, Taipei, Taiwan) system equipped with a refractive index detector and three Ultrastyragel columns $(100,500$, and $1000 \AA)$ connected in series. DMF was the eluent, at a flow rate of $1 \mathrm{~mL} / \mathrm{min}$, at $40^{\circ} \mathrm{C}$. DSC measurements were performed using a TA Q-20 system (TA Instrument, New Castle, DE, USA), under $\mathrm{N}_{2}$ as a purge gas $(50 \mathrm{~mL} / \mathrm{min}$ ), and at a heating rate of $20^{\circ} \mathrm{C} / \mathrm{min}$. The sample (ca. 5-7 mg) was placed in a sealed aluminum sample pan. The thermal stabilities of the homopolymers and alternating copolymers were investigated using a TA Q-50 thermogravimetric analyzer (TA Instrument, New Castle, DE, USA), under $\mathrm{N}_{2}$ as a purge gas $(60 \mathrm{~mL} / \mathrm{min})$, and at a heating rate of $20^{\circ} \mathrm{C} / \mathrm{min}$ from 30 to $800^{\circ} \mathrm{C}$. UV-vis spectra were recorded using a Shimadzu mini 1240 spectrophotometer (Shimadzu, Taipei, Taiwan). PL spectra were recorded at room temperature using a monochromatized Xe light source, solutions of polymers in THF at a concentration of $10^{-4} \mathrm{M}$, and an excitation wavelength of $330 \mathrm{~nm}$. The quantum efficiencies $\left(\Phi_{\mathrm{f}}\right)$ in solution and in the solid state were measured using an integrated sphere (Ocean Optics). WAXD profiles were measured using the wiggler beamline BL17A1 of the National Synchrotron Radiation Research Center (NSRRC) of Hsinchu, Taiwan. A triangular bent Si (111) single crystal was used to 
obtain a monochromated beam having a wavelength $(\lambda)$ of $1.32 \AA$. The samples were annealed prior to WAXD measurements.

\section{Results and Discussion}

\subsection{Synthesis of MIPOSS-2Br, MIPOSS-Br, and MIPOSS-NHBu}

In this study, observed unusually strong emissions from polymers containing butylamine maleimide isobutyl POSS NPs in the solid state and in solution and also investigated their application as metal ion sensors. First, we prepared MIPOSS-2Br through the reaction of MIPOSS with $\mathrm{Br}_{2}$ in dry $\mathrm{CHCl}_{3}$ at room temperature (Scheme $1 \mathrm{~b}$ ). A subsequent elimination reaction of MIPOSS-2Br with $\mathrm{Et}_{3} \mathrm{~N}$ in dry THF afforded MIPOSS-Br (Scheme 1c), thereafter used as a raw material for the high-yield synthesis of MIPOSS-NHBu (Scheme 1d). The chemical structures of all of the monomers synthesized in this study were confirmed using ${ }^{1} \mathrm{H}$ - and ${ }^{13} \mathrm{C}-\mathrm{NMR}$ and FTIR spectroscopies. Figure 1 displays the ${ }^{1} \mathrm{H}-\mathrm{NMR}$ spectra of MIPOSS-Br and MIPOSS-NHBu in $\mathrm{CDCl}_{3}$. The characteristic resonance of the $\mathbf{C} \underline{H}=\mathrm{C}$ units appeared as a signal at $6.69 \mathrm{ppm}$ for both MIPOSS-Br and MIPOSS-NHBu. The signal at $3.54 \mathrm{ppm}$ corresponded to the two protons of the $\mathrm{NC}_{2}{ }_{2} \mathrm{CH}_{2}$ unit, while the signal at $0.87 \mathrm{ppm}$ corresponded to the two protons of the $\mathrm{SiC}_{2} \mathrm{CH}_{2} \mathrm{CH}_{2}$ linkage between the maleimide ring and the POSS core. We assign the signals at 3.95 and $1.28 \mathrm{ppm}$ to the $\mathrm{NHCH}_{2} \mathrm{CH}_{2}$ and $\mathrm{NHCH}_{2} \mathbf{C H}_{2}$ units, respectively, of MIPOSS-NHBu (Figure $1 \mathrm{~b}$ ). Figure 2 presents the ${ }^{13} \mathrm{C}-\mathrm{NMR}$ spectra of MIPOSS-Br and MIPOSS-NHBu. The signal for the maleimide $\mathrm{C}=\mathrm{O}$ groups appeared at 169.03 and $166.72 \mathrm{ppm}$. For all of the maleimide isobutyl POSS monomers, the signals of the $\underline{\mathrm{C}} \mathrm{H}=\underline{\mathrm{C}}$ group were centered at 132.25 and $134.67 \mathrm{ppm}$, while those at 46.07 and $9.46 \mathrm{ppm}$ represented the resonances of the $\mathrm{SiCH}_{2} \mathrm{CH}_{2} \mathrm{CH}_{2} \mathrm{~N}$ methylene unit and the $\mathrm{SiCH}_{2} \mathrm{CH}\left(\mathrm{CH}_{3}\right)_{2}$ methine unit, respectively, of the POSS core. The significant downfield shift for the signal of the $\mathrm{CH}=\mathrm{C}$ group from $134.67 \mathrm{ppm}$ MIPOSS-Br to $149.79 \mathrm{ppm}$ for MIPOSS-NHBu confirmed the success of the substitution reaction.

Figure 3 presents the FTIR spectra of MIPOSS, MIPOSS-Br, and MIPOSS-NHBu. The characteristic absorption bands of the POSS core and the maleimide ring appeared at $2956-2878 \mathrm{~cm}^{-1}$ (aliphatic $\mathrm{CH}$ stretching); 1768 and $1714 \mathrm{~cm}^{-1}$ (asymmetric and symmetric imide $\mathrm{C}=\mathrm{O}$ stretching); $1636 \mathrm{~cm}^{-1}$ ( $\mathrm{C}=\mathrm{C}$ stretching); $1238 \mathrm{~cm}^{-1}$ ( $\mathrm{C}-\mathrm{N}$ bending); and $1110 \mathrm{~cm}^{-1}$ ( $\mathrm{Si}-\mathrm{O}-\mathrm{Si}$ stretching of POSS core); with a signal at $3445 \mathrm{~cm}^{-1}$ for N-H stretching of MIPOSS-NHBu appearing in Figure 3c. The NMR and FTIR spectra data indicated that we had successfully incorporated the alkyl chain in the maleimide isobutyl POSS NP unit.

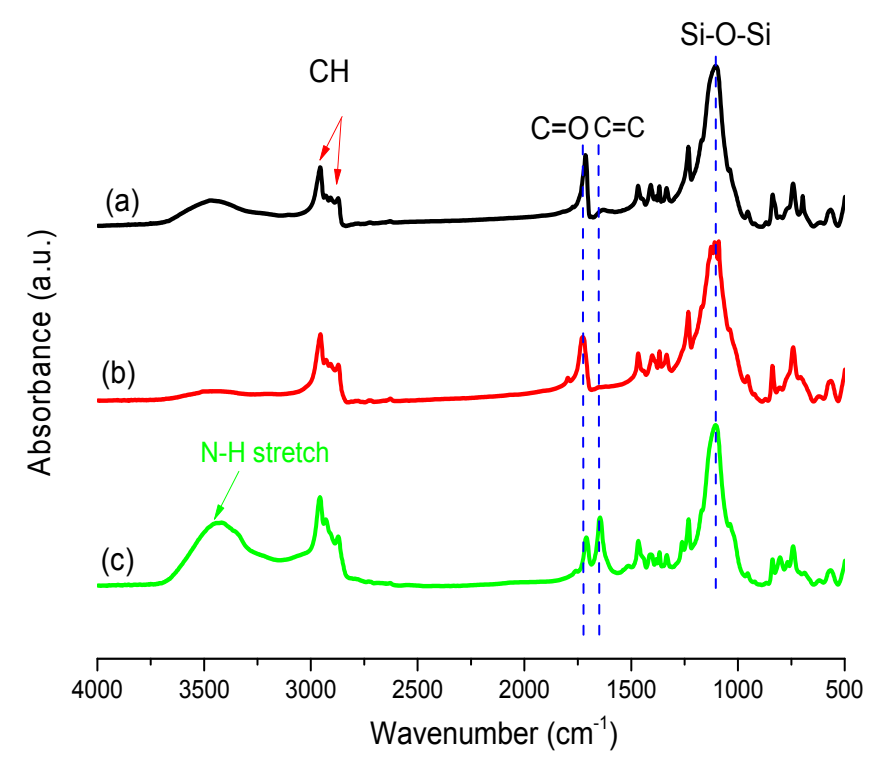

Figure 3. FTIR spectra of the monomers: (a) MIPOSS; (b) MIPOSS-Br; and (c) MIPOSS-NHBu. 
3.2. Synthesis of Poly(S-alt-MIPOSS-Br), Poly(S-alt-MIPOSS-NHBu), Poly(AS-alt-MIPOSS-NBu), and Poly(HS-alt-MIPOSS-NBu)

As mentioned above, the mechanical properties, oxidation resistance, and thermal stability of polymers can all increase after the incorporation of POSS NPs into a polymer matrix to form organic/inorganic nanocomposites. Therefore, in this current study, we prepared several MIPOSS-NHBu fluorophore-containing alternating copolymers: poly(S-alt-MIPOSS-Br), poly(S-alt-MIPOSS-NHBu), poly(AS-alt-MIPOSS-NHBu), and poly(HS-alt-MIPOSS-NHBu). We confirmed the molecular structures of these MIPOSS-NHBu-containing copolymers through ${ }^{1} \mathrm{H}-$, ${ }^{13} \mathrm{C}-$, and ${ }^{29} \mathrm{Si}-\mathrm{NMR}$ spectroscopic, FTIR spectroscopic, and GPC analyses.

Figure 4 displays the ${ }^{1} \mathrm{H}-\mathrm{NMR}$ spectra of these new alternating copolymers. The ${ }^{1} \mathrm{H}-\mathrm{NMR}$ spectrum of the poly(S-alt-MIPOSS-Br) copolymer (Figure 4a) features signals at 7.09-6.57 and $3.45 \mathrm{ppm}$ representing the aromatic and side chain protons of MIPOSS and the methylene protons in the $\mathrm{SiCH}_{2} \mathrm{CH}_{2} \mathrm{CH}_{2} \mathrm{~N}$ units. Other signals appeared at 1.82, 1.65, 0.94, and $0.60 \mathrm{ppm}$ corresponding to the $\mathrm{SiCH}_{2} \mathrm{C} \underline{\mathrm{H}}\left(\mathrm{CH}_{3}\right)_{2}$ methine, $\mathrm{SiCH}_{2} \mathrm{CH}_{2} \mathrm{CH}_{2} \mathrm{~N}$ methylene, $\mathrm{SiCH}{ }_{2} \mathrm{CH}\left(\mathrm{CH}_{3}\right)_{2}$ methyl, and both the $\mathrm{SiC}_{2} \mathrm{CH}_{2} \mathrm{CH}_{2} \mathrm{~N}$ and $\mathrm{SiCH}_{2} \mathrm{CH}\left(\mathrm{CH}_{3}\right)_{2}$ methylene protons, respectively [40,42]. The ${ }^{1} \mathrm{H}-\mathrm{NMR}$ spectra of poly(S-alt-MIPOSS-NHBu), poly(AS-alt-MIPOSS-NHBu), and poly(HS-alt-MIPOSS-NHBu) (Figure $4 \mathrm{~b}-\mathrm{d}$, respectively) feature their aromatic signals between 6.68 and $7.10 \mathrm{ppm}$. As displayed in Figure $4 \mathrm{~b}$ for poly(S-alt-MIPOSS-NHBu), the characteristic proton signals were centered at 2.95, 2.20, 1.30, and $0.95 \mathrm{ppm}$, attributed to the $\mathrm{NHCH}_{2} \mathrm{CH}_{2}, \mathrm{NHCH}_{2} \mathbf{C H}_{2}, \mathrm{NHCH}_{2} \mathrm{CH}_{2} \mathrm{CH}_{2}$, and $\mathrm{NHCH}_{2} \mathrm{CH}_{2} \mathrm{CH}_{2} \mathrm{CH}_{3}$ units, respectively. In addition, a peak appeared at $2.27 \mathrm{ppm}$ in Figure $4 \mathrm{c}$ for poly(AS-alt-MIPOSS-NHBu), corresponding to the methyl unit in the acetyl groups ( $\left.\mathrm{OCOC} \underline{\mathrm{H}}_{3}\right)$; this signal disappeared completely after hydrazine-mediated hydrolysis of the acetyl groups, affording poly(HS-alt-MIPOSS-NHBu) (Figure 4d), for which the signal of the OH groups appeared at $8.90 \mathrm{ppm}$ [42]. Scheme 2 summarizes the other peak assignments.

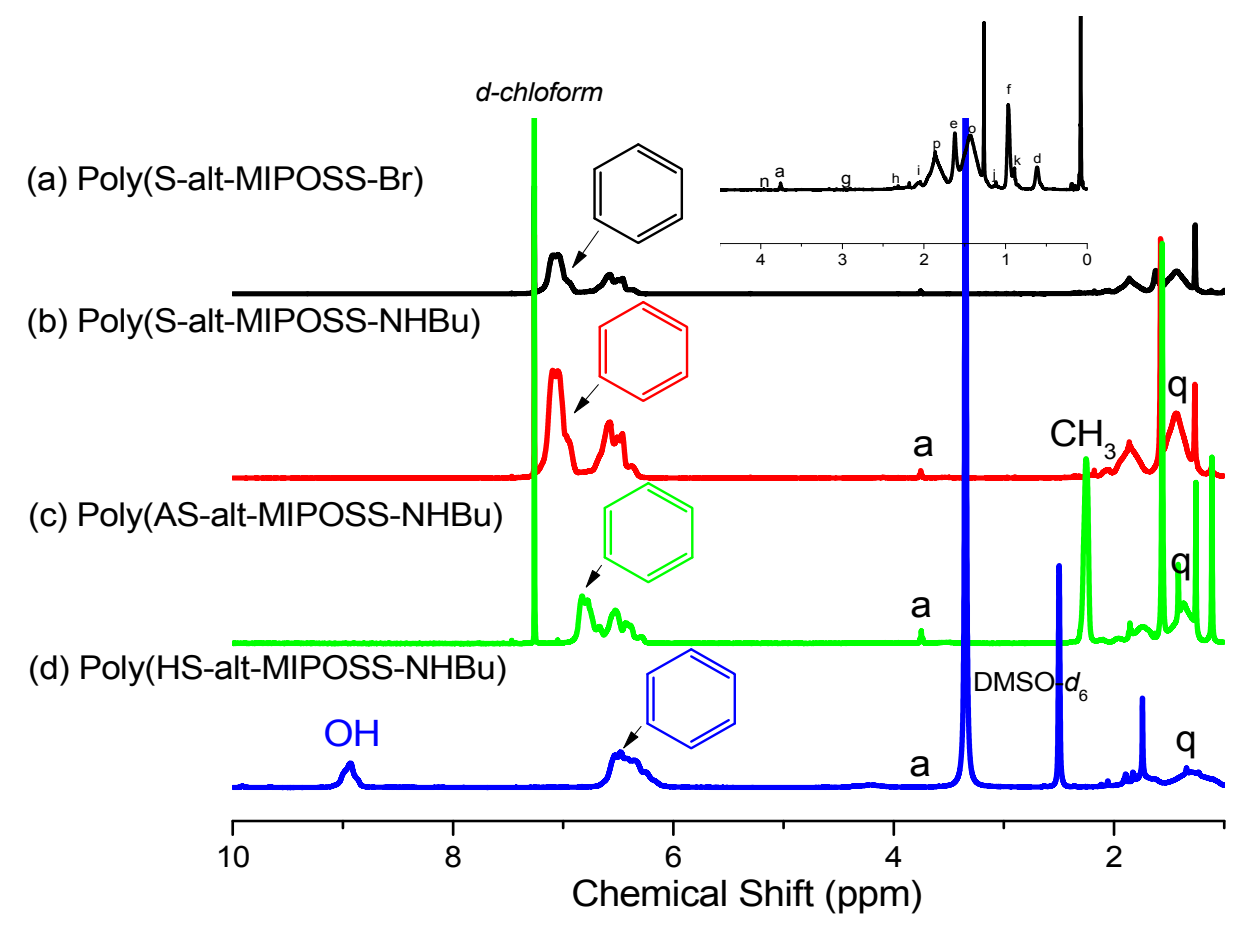

Figure 4. $\quad{ }^{1} \mathrm{H}-\mathrm{NMR}$ spectra of: (a) poly(S-alt-MIPOSS-Br); (b) poly(S-alt-MIPOSS-NHBu); (c) poly(AS-alt-MIPOSS-NHBu); and (d) poly(HS-alt-MIPOSS-NHBu).

Figure 5 presents the ${ }^{13} \mathrm{C}-\mathrm{NMR}$ spectra of these alternating copolymers in $\mathrm{CDCl}_{3}$ and DMSO- $d_{6}$. The ${ }^{13} \mathrm{C}-\mathrm{NMR}$ spectra of poly(S-alt-MIPOSS-Br), poly(S-alt-MIPOSS-NHBu), and poly(AS-alt-MIPOSS-NHBu) 
(Figure 5a-c, respectively) feature signals at 177.96, 146.58, 145.89, 125.88, 41.28 and $9.01 \mathrm{ppm}$ corresponding to the $\mathrm{C}=\mathrm{O}$ groups, aromatic moieties, $\mathrm{SiCH}_{2} \mathrm{CH}_{2} \mathrm{CH}_{2} \mathrm{~N}$ methylene units, and $\mathrm{SiCH}_{2} \mathrm{CH}\left(\mathrm{CH}_{3}\right)_{2}$ methine units, respectively. In Figure $5 \mathrm{~d}$, the signal from the aromatic rings at $155.87(\mathbf{P h O H}$, peak $\mathbf{u})$ had shifted from $149.3\left(\mathbf{P h}-\mathrm{OCOCH}_{3}\right)$ and $115.60 \mathrm{ppm}$ (peak $\left.\mathbf{t}\right)$ in Figure 5c; the absence of the signal for the $\mathrm{Ph}-\mathrm{OCOCH}_{3}$ group at $31.20 \mathrm{ppm}$ confirmed the successful hydrolysis of poly(HS-alt-MIPOSS-NHBu). Other peak assignment was also summarized in Scheme 2. We also recorded ${ }^{29} \mathrm{Si}-\mathrm{NMR}$ spectra of poly(S-alt-MIPOSS-Br), poly(S-alt-MIPOSS-NHBu), poly(AS-alt-MIPOSS-NHBu), and poly(HS-alt-MIPOSS-NHBu) to confirm the presence of their POSS cores and that no cage cleavage had occurred during the free radical copolymerizations of these alternating copolymers (Figure 6). Indeed, the ${ }^{29} \mathrm{Si}-\mathrm{NMR}$ spectra revealed signals at -54.03 (peak a) and -54.25 (peak b) ppm representing their $\mathrm{OSiCH}_{2} \mathrm{CH}_{2} \mathrm{CH}_{2} \mathrm{~N}$ and $\mathrm{OSiCH}_{2} \mathrm{CH}\left(\mathrm{CH}_{3}\right)_{2}$ units, respectively.

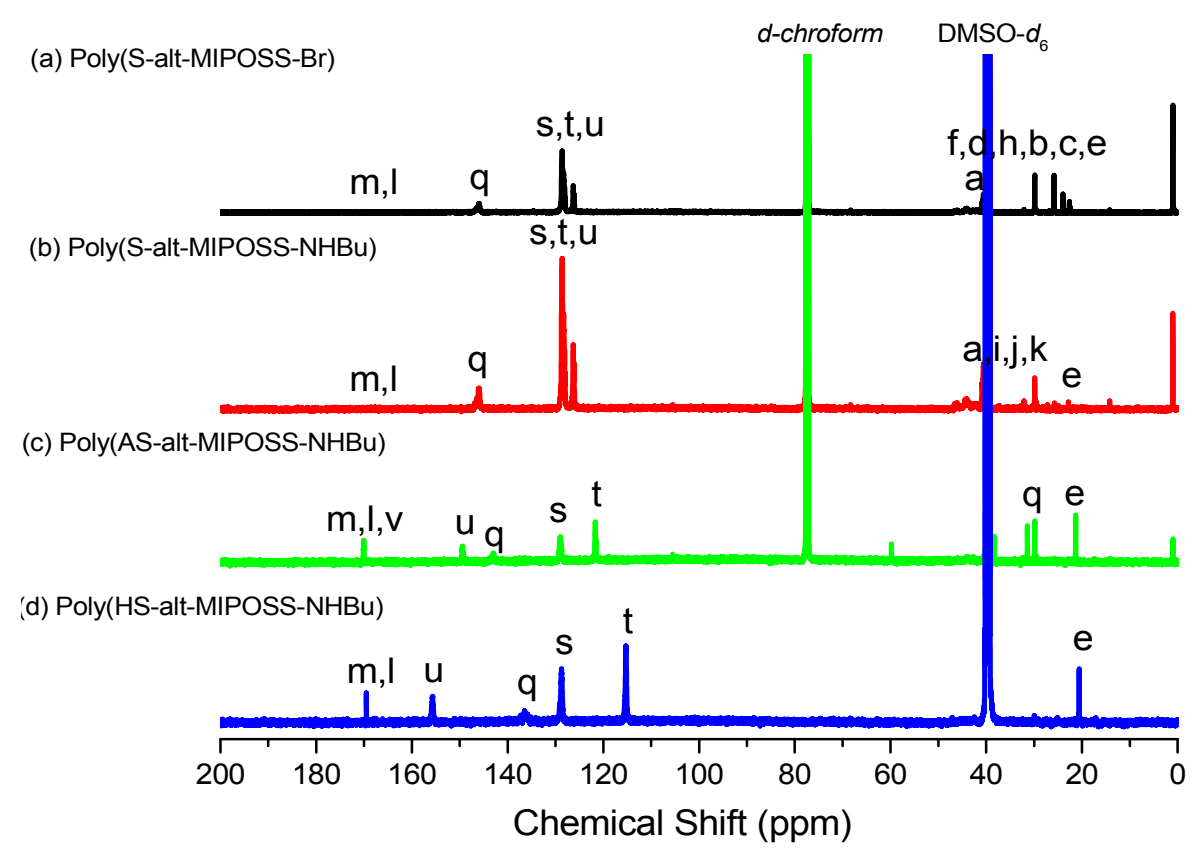

Figure 5. ${ }^{13} \mathrm{C}-\mathrm{NMR}$ spectra of (a) poly(S-alt-MIPOSS-Br); (b) poly(S-alt-MIPOSS-NHBu); (c) poly(AS-alt-MIPOSS-NHBu); and (d) poly(HS-alt-MIPOSS-NHBu).

Figure S3 displays the FTIR spectra of these alternating copolymers. Typical characteristic absorption bands for isobutyl $\mathrm{CH}$ stretching and $\mathrm{Si}-\mathrm{O}-\mathrm{Si}$ stretching of the maleimide isobutyl POSS structure in alternating copolymers appeared at 2920-2847 and $1105 \mathrm{~cm}^{-1}$, respectively, with the signal for the $\mathrm{C}=\mathrm{C}$ bond at $1634 \mathrm{~cm}^{-1}$ disappearing, consistent with the occurrence of free radical copolymerization. The spectrum of poly(AS-alt-MIPOSS-NHBu) (Figure S3c) features a typical absorption band at $1768 \mathrm{~cm}^{-1}$ for $\mathrm{C}=\mathrm{O}$ stretching of the acetyl groups in the AS units. This signal was absent in the spectrum of poly(HS-alt-MIPOSS-NHBu) (Figure S3d); instead, it displayed an absorption band at $3312 \mathrm{~cm}^{-1}$ for $\mathrm{OH}$ stretching in the HS units, confirming the successful hydrolysis of poly(HS-alt-MIPOSS-NHBu). The GPC profiles (Figure S4) of these new alternating copolymers displayed unimodal curves which were prepared via free radical polymerization process; Table 1 summarizes the data obtained for these alternating copolymers. 


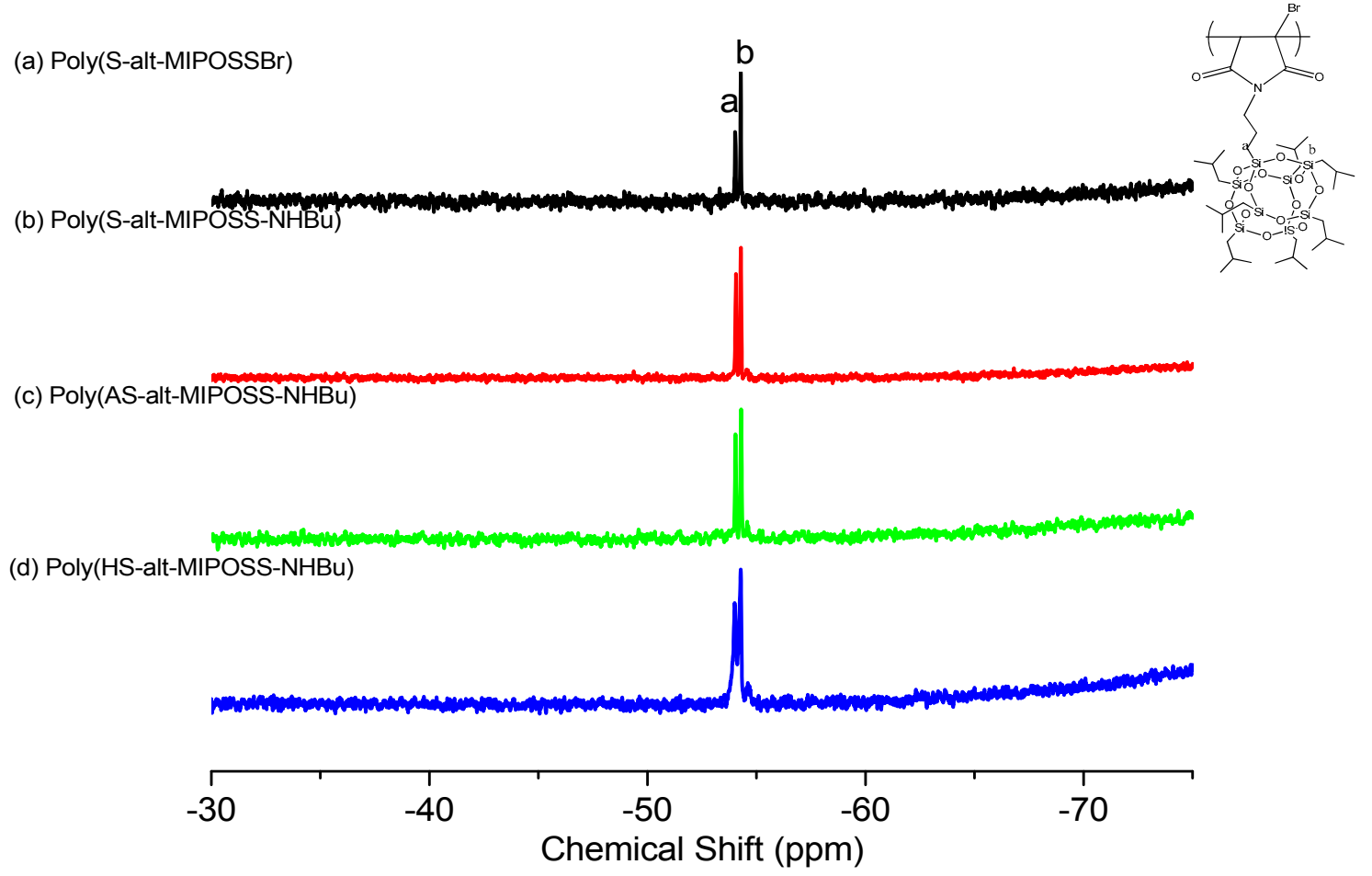

Figure 6. ${ }^{29} \mathrm{Si}-\mathrm{NMR}$ spectra of: (a) poly(S-alt-MIPOSS-Br); (b) poly(S-alt-MIPOSS-NHBu); (c) poly(AS-alt-MIPOSS-NHBu); and (d) poly(HS-alt-MIPOSS-NHBu). Inset figure is corresponding to the chemical structure and peak assignment of ${ }^{29} \mathrm{Si}$ NMR of poly(MIPOSS-Br).

Table 1. Molecular weights, glass transition temperatures, and quantum yields of the alternating copolymers.

\begin{tabular}{ccccccc}
\hline Sample & $\boldsymbol{M}_{\mathbf{n}}{ }^{\mathbf{a}}$ & $\boldsymbol{M}_{\mathbf{w}}{ }^{\mathbf{a}}$ & $\mathbf{P D I}^{\mathbf{a}}$ & $\boldsymbol{T}_{\mathbf{g}}{ }^{\mathbf{b}}\left({ }^{\circ} \mathbf{C}\right)$ & $\boldsymbol{T}_{\mathbf{d}}{ }^{\mathbf{c}}\left({ }^{\circ} \mathbf{C}\right)$ & Quantum Yield $^{\mathbf{d}}(\%)$ \\
\hline S-alt-MIPOSS-Br & 23,900 & 40,000 & 1.67 & 83 & 364 & 52.4 \\
S-alt-MIPOSS-NHBu & 10,900 & 18,964 & 1.74 & 81 & 355 & 78.8 \\
AS-alt-MIPOSS-Br & 74,200 & 106,200 & 1.43 & 119 & 356 & 63.2 \\
AS-alt-MIPOSS-NHBu & 26,800 & 46,000 & 1.71 & 105 & 326 & 93.8 \\
HS-alt-MIPOSS-NHBu & 65,300 & 95,900 & 1.46 & 130 & 320 & 31.4 \\
\hline
\end{tabular}

${ }^{a}$ Measured through GPC analysis; ${ }^{b}$ Measured through DSC; ${ }^{c}$ Measured through TGA; ${ }^{d}$ Measured using an integrated sphere (Ocean Optics).

\subsection{Thermal Properties of Monomers and Alternating Copolymers}

We employed DSC under a $\mathrm{N}_{2}$ atmosphere to investigate the thermal properties of the monomers and alternating copolymers. Figure S5 presents the endothermic melting temperatures of MIPOSS, MIPOSS-2Br, MIPOSS-Br, and MIPOSS-NHBu. The melting temperature $\left(T_{\mathrm{m}}\right)$ of the MIPOSS monomer was higher $\left(171^{\circ} \mathrm{C}\right)$ than those of MIPOSS-2Br $\left(129^{\circ} \mathrm{C}\right)$, MIPOSS-Br $\left(168{ }^{\circ} \mathrm{C}\right)$, and MIPOSS-NHBu $\left(118^{\circ} \mathrm{C}\right)$, presumably because of the higher degrees of crystallinity and molecular packing of MIPOSS. Figure 7 presents DSC thermograms of the MIPOSS-NHBu monomer and the poly(S-alt-MIPOSS-NHBu), poly(AS-alt-MIPOSS-NHBu) and poly(HS-alt-MIPOSS-NHBu) copolymers, recorded under a $\mathrm{N}_{2}$ atmosphere. The DSC profile of the MIPOSS-NHBu monomer (Figure 7a) features an endothermic melting point near $118^{\circ} \mathrm{C}$, possibly representing aggregation or the crystalline structure of the POSS units. Lower crystallinity was evident for these three alternating copolymers, with the glass transition temperature $\left(T_{\mathrm{g}}\right)$ of poly(HS-alt-MIPOSS-NHBu) $\left(130^{\circ} \mathrm{C}\right)$ higher than those of poly(AS-alt-MIPOSS-NHBu) $\left(105^{\circ} \mathrm{C}\right)$ and poly(S-alt-MIPOSS-NHBu) $\left(81^{\circ} \mathrm{C}\right)$, presumably because of intermolecular hydrogen bonding among the $\mathrm{OH}$ groups in the HS segments. 


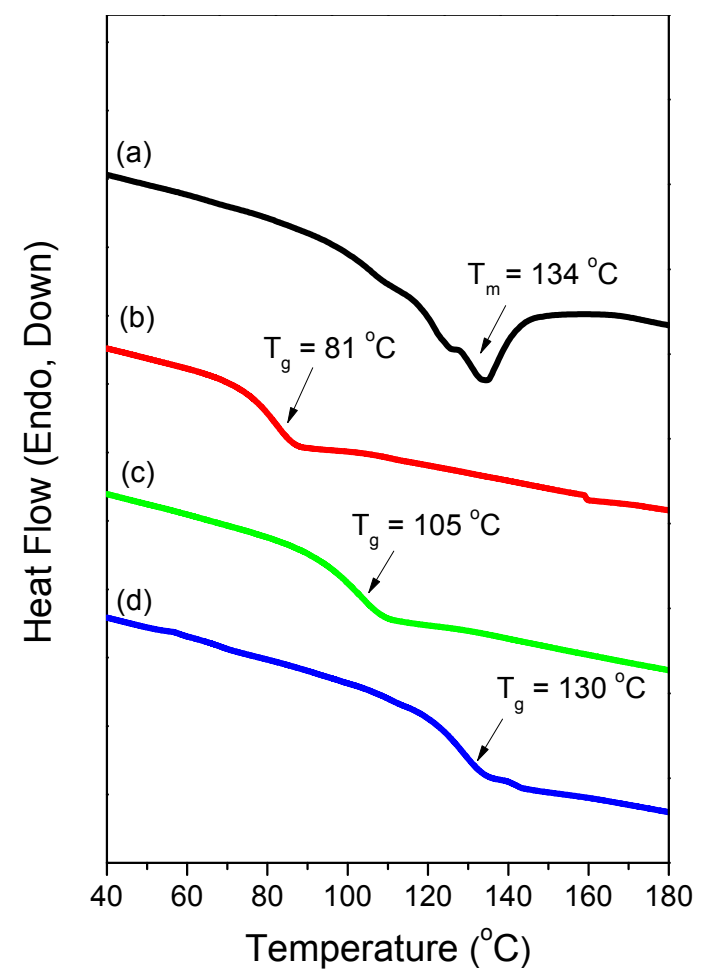

Figure 7. DSC thermograms of: (a) MIPOSS-NHBu; (b) poly(S-alt-MIPOSS-NHBu); (c) poly(AS-altMIPOSS-NHBu); and (d) poly(HS-alt-MIPOSS-NHBu).

We used TGA under a $\mathrm{N}_{2}$ atmosphere to determine the decomposition temperatures and char yields of these alternating copolymers (Figure S6). The degradation temperatures and char yields of poly(S-alt-MIPOSS-Br) and poly(S-alt-MIPOSS-NHBu) were higher than those of the standard PS homopolymer $\left(337^{\circ} \mathrm{C}\right.$ and $0 \%$, respectively) because of the steric bulk of the rigid-cage MIPOSS units and the readier pyrolysis of the PS main chain $[51,52]$. The degradation temperature and char yield of alkylamine-functionalized poly(S-alt-MIPOSS-NHBu) $\left(355^{\circ} \mathrm{C}\right.$ and $6.9 \%$, respectively) were lower than those of the bromine-functionalized poly(S-alt-MIPOSS-Br) $\left(364{ }^{\circ} \mathrm{C}\right.$ and $12.2 \%$, respectively); this behavior was expected because an alkyl chain possesses thermal stability lower than that of a bromide group. To examine the crystalline properties of the synthesized maleimide POSS derivatives and the amorphous characteristics of the alternating copolymers, we performed WAXD analyses at room temperature (Figure 8). The WAXD spectrum in Figure 8a features four diffraction peaks at 6.97 (101), 9.40 (110), 10.39 (102) and 16.29 (113) that correspond to the rhombohedral crystal structure of the MIPOSS unit (Figure S7). After introduction of S, AS, and HS units as inert diluent segments for the MIPOSS-NHBu units in poly(S-alt-MIPOSS-NHBu), poly(AS-alt-MIPOSS-NHBu), and poly(HS-alt-MIPOSS-NHBu), the WAXD profiles featured only broad amorphous halos and revealed the destruction of the crystalline structure of the MIPOSS unit (Figure 8b-d). The spectra of all the alternating copolymers exhibited two major sharp diffraction peaks at values of $2 \theta$ of $4.85^{\circ}$ and $9.6^{\circ}$, representing $d$-spacing of 1.59 and $0.80 \mathrm{~nm}$, respectively [55]; the first peak is consistent with the average distance between the POSS cages in the MIPOSS segment, while the other is due to the average distance between the maleimide groups of the MI-POSS segments [55]. The formed $d$-spacing is larger than that found for the pure PMAPOSS segment ( $d=1.0$ and $0.49 \mathrm{~nm}$ ) [58], presumably because the functional NHBu groups on the main chain and inserted styrene-based segments into the MIPOSS-NHBu units expanded the $d$-spacing of these alternating copolymers, as displayed in inset scheme of Figure 8. Herein, we also observed that the full-width at half maximum of these two peaks did not change, indicating that the particle size of POSS did not change after incorporation after introduction of S, AS, and HS units into MIPOSS-NHBu segment. Thus, the maleimide monomer and 
the alternating copolymers possessed crystalline and amorphous structures, respectively, consistent with the results of the DSC analyses in Figure 7.

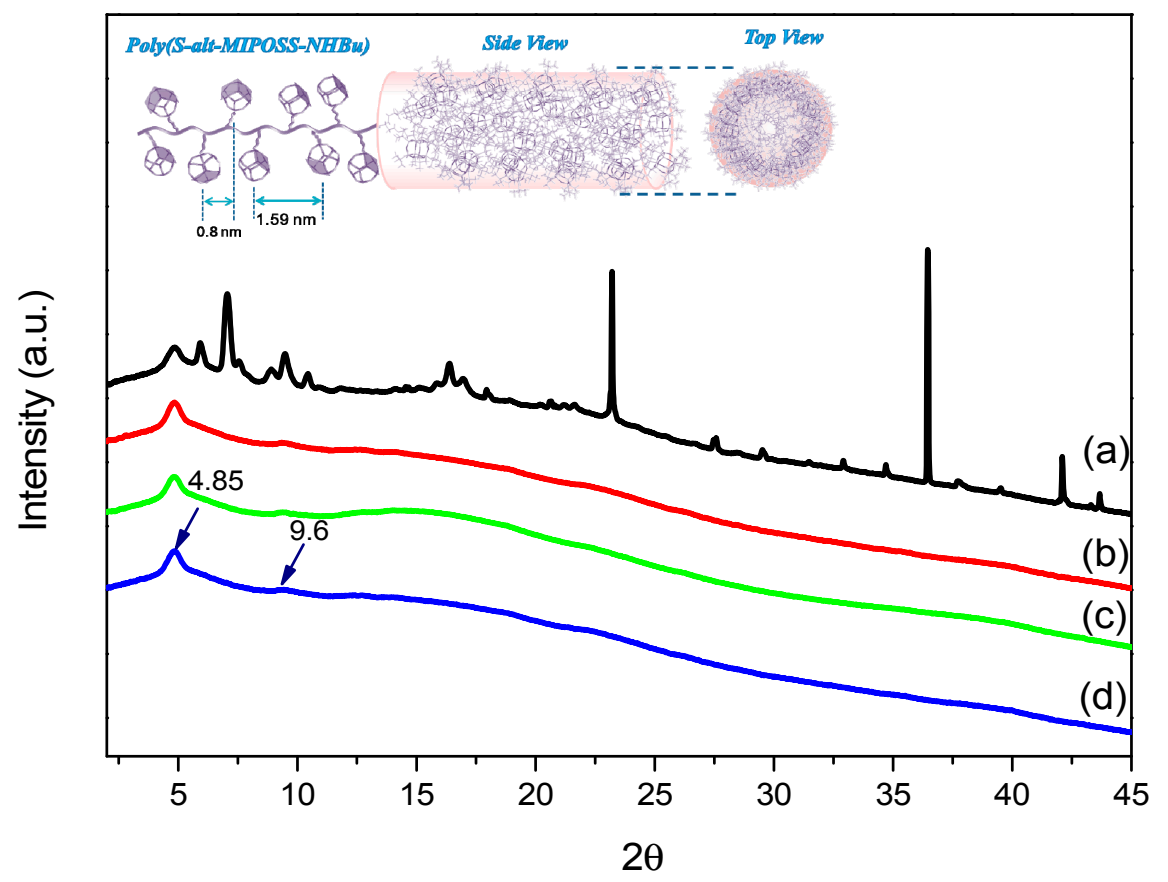

Figure 8. WAXD patterns of: (a) MIPOSS-NHBu; (b) poly(S-alt-MIPOSS-NHBu); (c) poly(AS-altMIPOSS-NHBu); and (d) poly(HS-alt-MIPOSS-NHBu). Inset Figure: the scheme about the $d$-spacing of poly(S-alt-MIPOSS-NHBu) alternating copolymer.

\subsection{Optical Properties}

Next, we studied the relationship between the molecular structure and photophysical properties in solid state and solution state for the series of maleimide and succinimide isobutyl POSS derivatives containing 2-butylamino units. Figure S8 shows the UV-vis spectra of MIPOSS, MIPOSS-2Br, MIPOSS-Br and MIPOSS-NHBu in dichloromethane solution $\left(10^{-4} \mathrm{M}\right)$. These monomers exhibited absorptions peaks at 234, 235, 245 and $236 \mathrm{~nm}$, respectively which can be attributed to a $\pi-\pi^{*}$ transitions. Figure 9 displays the PL spectra of maleimide and succinimide isobutyl POSS in the solid state. Interestingly, MIPOSS-NHBu display an unusual fluorescence, with a strong emission peak near $506.6 \mathrm{~nm}$, resulting from the spatial separation of the highest occupied molecular orbital (HOMO) and lowest unoccupied molecular orbital (LUMO), based on density functional theory calculations as reported in previous literature [34]. In contrast, MIPOSS-2Br and MIPOSS-Br did not show any emission peak, presumably because of the internal heavy atom effects of their bromine atoms. Figure S10 displays the UV-vis absorption spectra of poly(S-alt-MIPOSS-Br), poly(S-alt-MIPOSS-NHBu), poly(AS-alt-MIPOSS-Br), and poly(AS-alt-MIPOSS-NHBu) in dichloromethane solution $\left(10^{-4} \mathrm{M}\right)$. These alternating copolymers showed absorption peaks at 259, 258, 257 and 243, $264 \mathrm{~nm}$, respectively which can be due to a $\pi-\pi^{*}$ and $n-\pi^{*}$ transitions.

Figure 10 presents the PL spectra of poly(S-alt-MIPOSS-Br), poly(AS-alt-MIPOSS-Br), poly(S-alt-MIPOSS-NHBu), poly(AS-alt-MIPOSS-NHBu), and poly(HS-alt-MIPOSS-NHBu) in the solid state, with excitation at $330 \mathrm{~nm}$. The spectra of the oxygenic non-conjugated poly(S-alt-MIPOSS-NHBu) and poly(AS-alt-MIPOSS-NHBu) both featured strong emission peaks at 492.3 and $493.3 \mathrm{~nm}$, presumably because of the higher degrees of clustering of their locked $\mathrm{C}=\mathrm{O}$ groups. In contrast, the spectrum of poly(HS-alt-MIPOSS-NHBu) featured two weak fluorescence signals of low intensity at 419.0 and $506.2 \mathrm{~nm}$, resulting from the $\pi-\pi$ interactions of the phenyl rings and $\mathrm{C}=\mathrm{O}$ groups in the poly(MIPOSS) segments. The unexpected strong fluorescence of poly(AS-alt-MIPOSS-NHBu) 
in the solid state, relative to those of the other alternating copolymers, was presumably caused by:

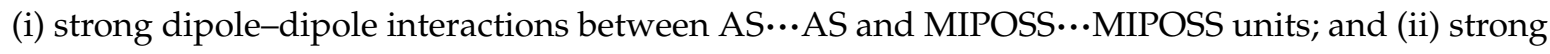
intermolecular hydrogen bonding between the $\mathrm{NH}$ groups from the MIPOSS-NHBu segments and the $\mathrm{C}=\mathrm{O}$ groups from the AS segments; together, these effects hindered the free rotation of the copolymer chains about the $\mathrm{C}-\mathrm{C}$ single bonds and, thereby, enhanced the emission of poly(AS-alt-MIPOSS-NHBu). The measured quantum efficiencies $\left(\Phi_{\mathrm{f}}\right)$ of poly(S-alt-MIPOSS-NHBu), poly(AS-alt-MIPOSS-NHBu), and poly(HS-alt-MIPOSS-NHBu) in the solid state were $78.8 \%, 93.8 \%$, and $31.4 \%$, respectively. Compared with poly(S-alt-MIPOSS), poly(S-alt-MIPOSS-NHBu) exhibited its unexpectedly strong emission enhancement because the 2-amino-succinimide unit underwent intramolecular hydrogen bonding with the $\mathrm{C}=\mathrm{O}$ groups of the MIPOSS units to lock the $\mathrm{C}=\mathrm{O}$ groups in the MIPOSS units.

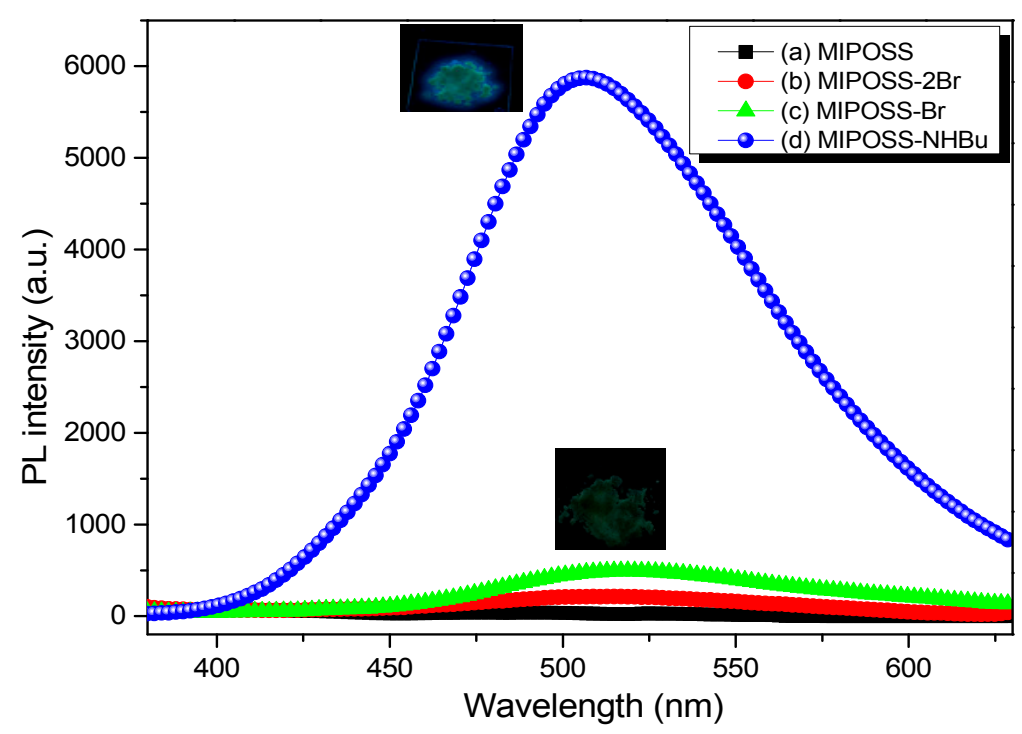

Figure 9. PL spectra of: (a) MIPOSS; (b) MIPOSS-2Br; (c) MIPOSS-Br; and (d) MIPOSS-NHBu, in the solid state (excitation: $330 \mathrm{~nm}$ ). Top insert figure is photo image for MIPOSS-NHBu and the bottom insert figure is photo image for MIPOSS-Br under excitation at $330 \mathrm{~nm}$.

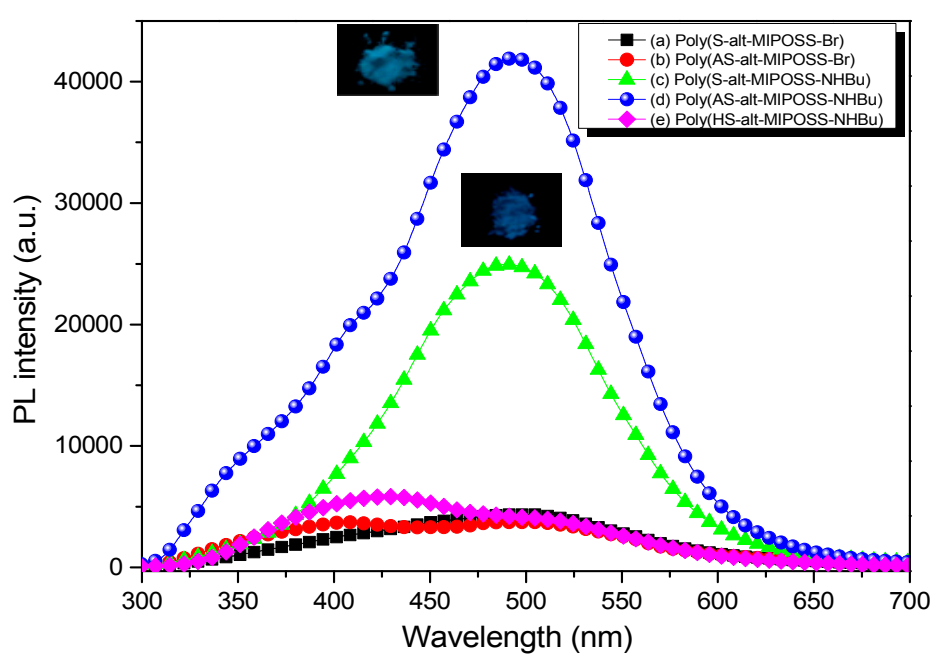

Figure 10. PL spectra of: (a) poly(S-alt-MIPOSS-Br); (b) poly(AS-alt-MIPOSS-Br) MIPOSS; (c) poly(S-alt-MIPOSS-NHBu; (d) poly(AS-alt-MIPOSS-NHBu); and (e) poly(HS-alt-MIPOSS-NHBu), in the solid state (excitation: $330 \mathrm{~nm}$ ). Top insert figure is photo image for poly(AS-alt-MIPOSS-NHBu) and the bottom insert figure is photo image for poly(S-alt-MIPOSS-NHBu) under excitation at $330 \mathrm{~nm}$. 
Figure 11 presents the PL spectra of MIPOSS-NHBu, poly(S-alt-MIPOSS-NHBu) and poly(AS-alt-MIPOSS-NHBu) as solutions in THF at various concentrations, with excitation at $330 \mathrm{~nm}$. Upon increasing the concentrations of the monomer and polymers (from $10^{-5}$ to $10^{-2} \mathrm{M}$ ) in THF (a good solvent), the emission intensities increased. On the other hand, the fluorescence intensities of these oxygenic nonconjugated components decreased in dilute solutions. These results suggest that these materials may be AIE materials. The MIPOSS-NHBu monomer has good solubility in hexane, DCM, 1,4-dioxane, acetone, EA, and DMSO; poly(S-alt-MIPOSS-NHBu) was soluble in DCM, 1,4-dioxane, and acetone. We investigated the effects of polar/nonpolar solvents and the environment on the emission behavior of MIPOSS-NHBu and poly(S-alt-MIPOSS-NHBu). The nitrogen atom of the $\mathrm{NH}$ group is an electron donor and the $\mathrm{C}=\mathrm{O}$ group in MIPOSS-NHBu is an electron acceptor. Thus, we might expect MIPOSS-NHBu and poly(S-alt-MIPOSS-NHBu) to be highly sensitive to solvents because electron transfer should occur from the $\mathrm{N}$ atoms to the $\mathrm{C}=\mathrm{O}$ groups in the imide units.

Figure 12 reveals that both MIPOSS-NHBu and poly(S-alt-MIPOSS-NHBu) have high fluorescence intensities in DCM. In the aprotic solvents acetone and DMSO, the PL intensities of MIPOSS-NHBu and poly(S-alt-MIPOSS-NHBu) decreased significantly, due to the formation of hydrogen bonds between the $\mathrm{NH}$ groups in the MIPOSS-NHBu units and the $\mathrm{S}=\mathrm{O}$ (in DMSO) and $\mathrm{C}=\mathrm{O}$ (in acetone) groups, and also intramolecular charge transfer that weakened the intramolecular hydrogen bonding with the $\mathrm{C}=\mathrm{O}$ groups of MIPOSS. Based on the concentration-enhanced emissions in Figure 11, we predicted that MIPOSS-NHBu, poly(S-alt-MIPOSS-NHBu), and poly(AS-alt-MIPOSS-NHBu) would be AIE materials. To confirm our hypothesis, we recorded PL spectra of MIPOSS-NHBu, poly(S-alt-MIPOSS-NHBu), and poly(AS-alt-MIPOSS-NHBu) in THF/ $\mathrm{H}_{2} \mathrm{O}$ mixtures as a solvent pair. For MIPOSS-NHBu, upon increasing the $\mathrm{H}_{2} \mathrm{O}$ content from $0 \%$ to $50 \%$ (Figure 13 and Figure S9), the emission intensities decreased dramatically; the emission was enhanced again when the $\mathrm{H}_{2} \mathrm{O}$ content was $60 \%$, but did not return to the original level. Similar phenomena occurred for poly(S-alt-MIPOSS-NHBu) and poly(AS-alt-MIPOSS-NHBu) in THF/ $\mathrm{H}_{2} \mathrm{O}$ mixtures (Figure S11).

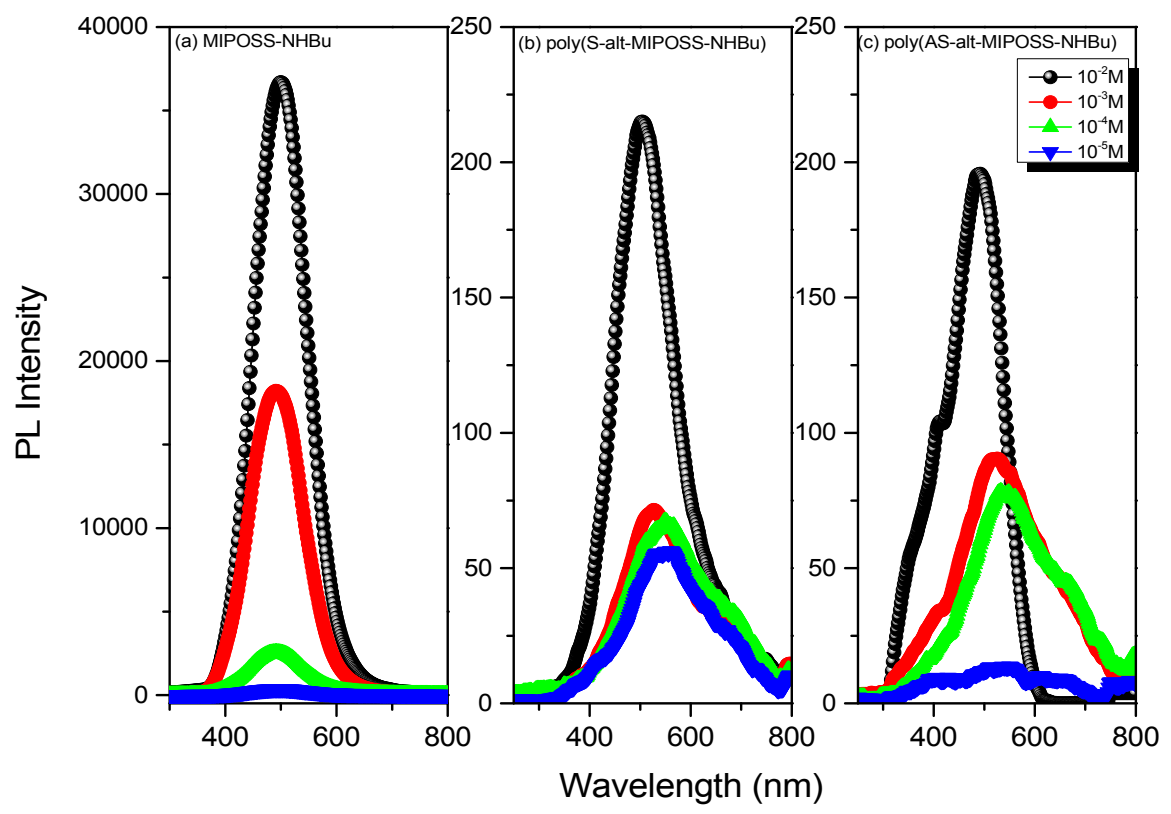

Figure 11. Fluorescence spectra of: (a) MIPOSS-NHBu monomer; (b) poly(S-alt-MIPOSS-NHBu); and (c) poly(AS-alt-MIPOSS-NHBu), in THF at concentrations from $10^{-5}$ to $10^{-2} \mathrm{M}$ (excitation: $330 \mathrm{~nm}$ ).

The PL intensities of poly(S-alt-MIPOSS-NHBu) and poly(AS-alt-MIPOSS-NHBu) increased upon increasing the $\mathrm{H}_{2} \mathrm{O}$ content from $40 \%$ to $50 \%$. We assign the decreases in the emission intensities of MIPOSS-NHBu, poly(S-alt-MIPOSS-NHBu), and poly(AS-alt-MIPOSS-NHBu) to the high polarity of $\mathrm{H}_{2} \mathrm{O}$; this behavior generally occurs in donor-acceptor luminogens. Therefore, 
MIPOSS-NHBu, poly(S-alt-MIPOSS-NHBu), and poly(AS-alt-MIPOSS-NHBu) displayed weak AIEE activity in solution. We also measured the quantum efficiencies $\left(\Phi_{\mathrm{f}}\right)$ of maleimide, succinimide isobutyl POSS, and the novel alternating copolymers in the solid state and in solution; Table S1 summarizes the values. Furthermore, we used dynamic light scattering (DLS) to measure the sizes of the particles of MIPOSS-NHBu, poly(S-alt-MIPOSS-NHBu), and poly(AS-alt-MIPOSS-NHBu) in the THF $/ \mathrm{H}_{2} \mathrm{O}$ mixtures (Figures S12 and S13). Upon increasing the $\mathrm{H}_{2} \mathrm{O}$ content from $40 \%$ to $50 \%$ to $60 \%$, the sizes of nanoaggregate structures formed from MIPOSS-NHBu decreased from 273 to 161 to $57 \mathrm{~nm}$ (Figure S12). Upon increasing the $\mathrm{H}_{2} \mathrm{O}$ content from 40, 50, 60 and 80, the sizes of NPs for poly(S-alt-MIPOSS-NHBu) were $886,423,303$ and $187 \mathrm{~nm}$, respectively, while for poly(AS-alt-MIPOSS-NHBu) they were 1102, 808, 724 and $255 \mathrm{~nm}$, respectively (Figure 13).

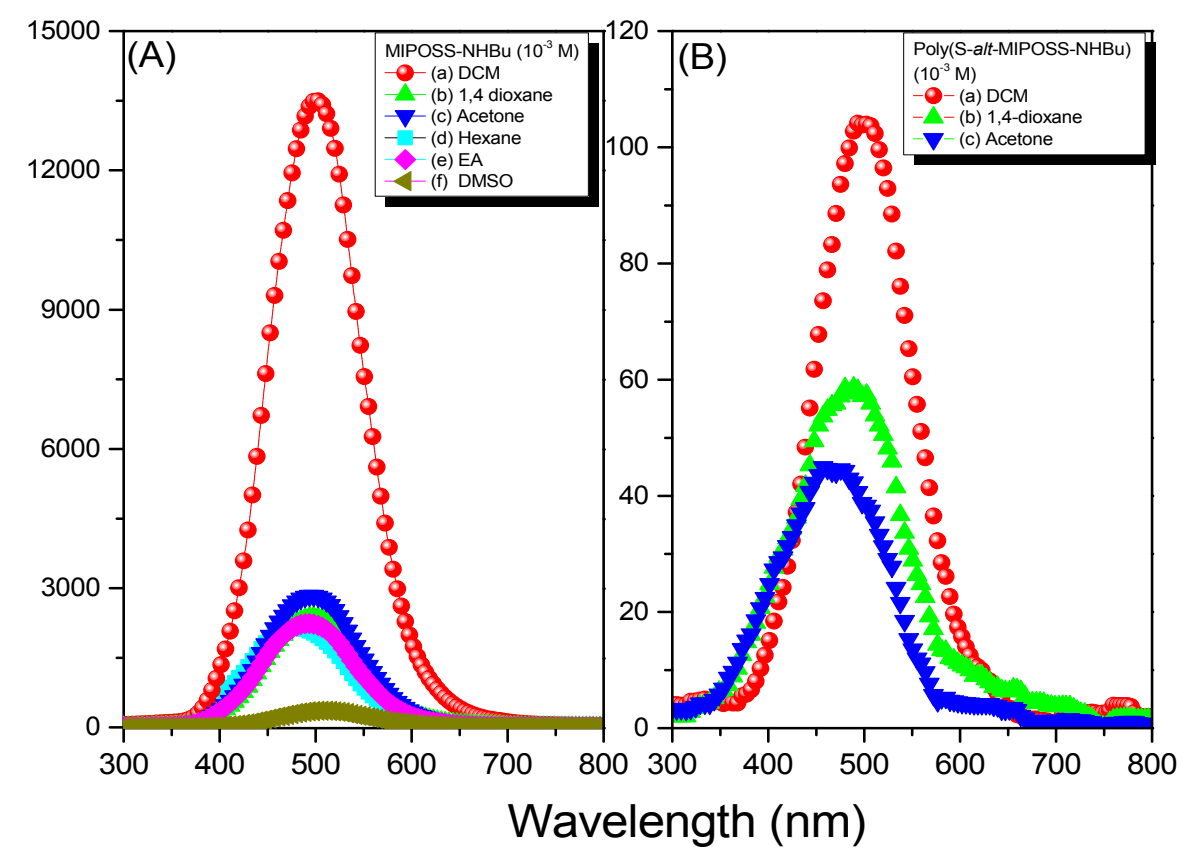

Figure 12. Fluorescence spectra of the: (A) monomer MIPOSS-NHBu; and (B) copolymer poly(S-alt-MIPOSS-NHBu), in various solvents at a concentration of $10^{-4} \mathrm{M}$ (excitation: $330 \mathrm{~nm}$ ).

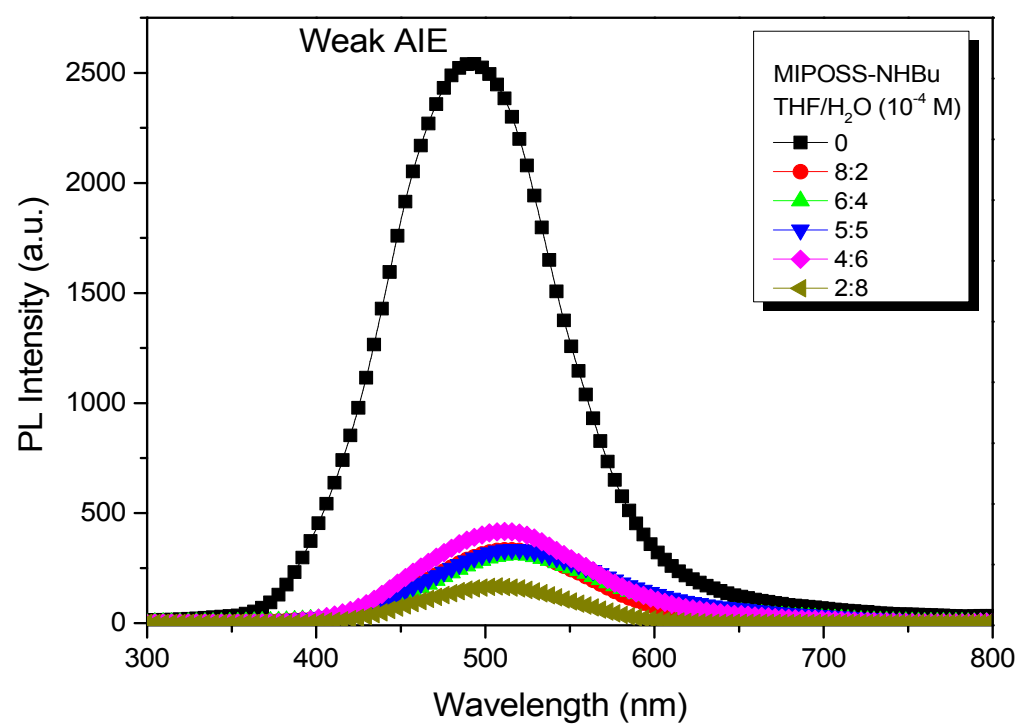

Figure 13. Fluorescence spectra of the monomer MIPOSS-NHBu, in $\mathrm{THF} / \mathrm{H}_{2} \mathrm{O}$ at various ratios at a concentration of $10^{-4} \mathrm{M}$ (excitation: $330 \mathrm{~nm}$ ). 


\subsection{Fluorescence Responses of MIPOSS-NHBu and Poly(AS-alt-MIPOSS-NHBu) toward Metal Ions}

We examined the selectivity response of solutions of MIPOSS-NHBu and poly(AS-altMIPOSS-NHBu $)$ in THF $\left(10^{-3} \mathrm{M}\right)$ to five different metal cations: $\mathrm{Zn}^{2+}, \mathrm{Fe}^{3+}, \mathrm{Cu}^{2+}, \mathrm{Al}^{3+}$, and $\mathrm{In}^{3+}$. For MIPOSS-NHBu, the PL emission intensity decreased slightly upon the addition $\mathrm{Zn}^{2+}, \mathrm{Al}^{3+}$, and $\mathrm{In}^{3+}$, relative to the original state, but it decreased significantly upon the addition of $\mathrm{Fe}^{3+}$ and $\mathrm{Cu}^{2+}$ (Figure 14). Poly(AS-alt-MIPOSS-NHBu) (Figure 15) exhibited similar phenomena, presumably because of the formation of strong $\mathrm{Fe}^{3+}$ and $\mathrm{Cu}^{2+}$ complexes with the $\mathrm{C}=\mathrm{O}$ groups in the imide units and with the $\mathrm{NH}$ groups, through metal-ligand interactions.

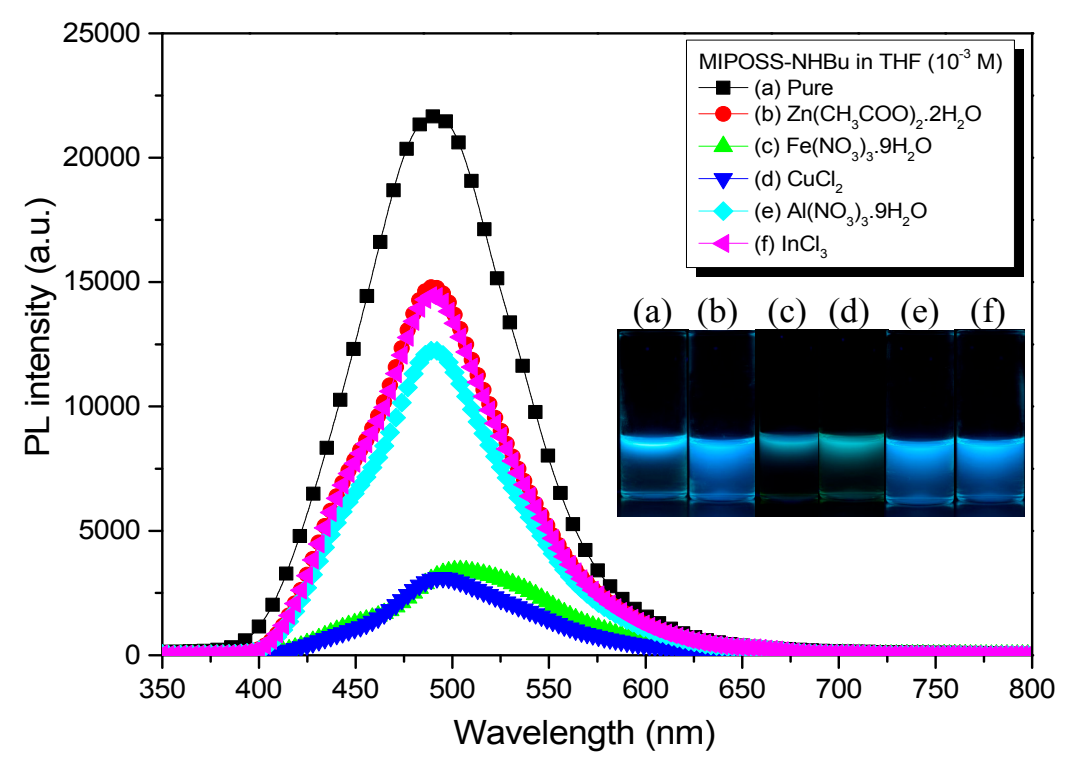

Figure 14. Fluorescence spectra (excitation: $330 \mathrm{~nm}$ ) of the monomer MIPOSS-NHBu (concentration: $10^{-3} \mathrm{M}$ ) in the presence of various metal ions: (a) pure MIPOSS-NHBu; (b) $\mathrm{Zn}\left(\mathrm{CH}_{3} \mathrm{COO}\right)_{2} \cdot 2 \mathrm{H}_{2} \mathrm{O}$; (c) $\mathrm{Fe}\left(\mathrm{NO}_{3}\right)_{2} \cdot 9 \mathrm{H}_{2} \mathrm{O} ;$ (d) $\mathrm{CuCl}_{2} ;\left(\right.$ e) $\mathrm{Al}\left(\mathrm{NO}_{3}\right)_{3} \cdot 9 \mathrm{H}_{2} \mathrm{O}$; and (f) $\mathrm{InCl}_{3}$.

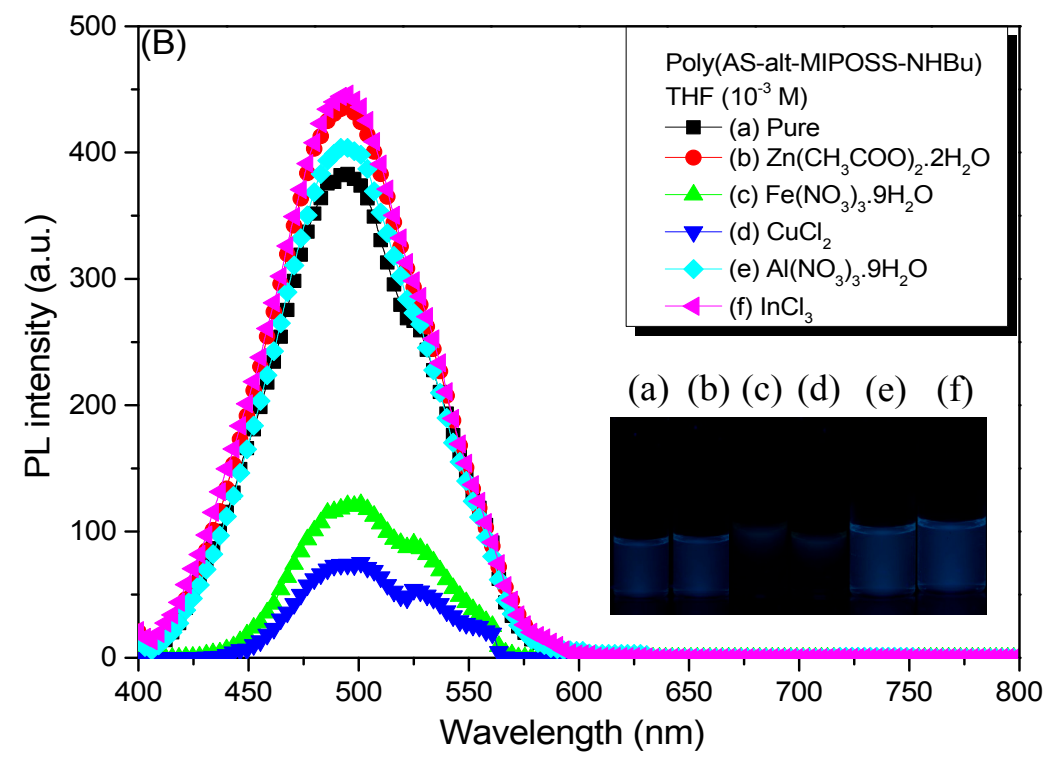

Figure 15. Fluorescence spectra (excitation: $330 \mathrm{~nm}$ ) of the copolymer poly(AS-alt-MIPOSS-NHBu) (concentration: $10^{-3} \mathrm{M}$ ) in the presence of various metal ions: (a) pure MIPOSS-NHBu; (b) $\mathrm{Zn}\left(\mathrm{CH}_{3} \mathrm{COO}\right)_{2} \cdot 2 \mathrm{H}_{2} \mathrm{O}$; (c) $\mathrm{Fe}\left(\mathrm{NO}_{3}\right)_{2} \cdot 9 \mathrm{H}_{2} \mathrm{O}$; (d) $\mathrm{CuCl}_{2}$; (e) $\mathrm{Al}\left(\mathrm{NO}_{3}\right)_{3} \cdot 9 \mathrm{H}_{2} \mathrm{O}$; and (f) $\mathrm{InCl}_{3}$. 


\section{Conclusions}

We have synthesized the monomer MIPOSS-NHBu and the alternating copolymers poly(S-alt-MIPOSS-NHBu), poly(AS-alt-MIPOSS-NHBu), and poly(AS-alt-MIPOSS-NHBu) through free radical copolymerizations, with their structures confirmed using NMR and FTIR spectroscopy. Thermal analyses revealed that the thermal stabilities and char yields of the POSS-containing alternating copolymers improved after incorporating the inorganic MIPOSS units. WAXD analyses indicated that these POSS-containing alternating polymers were amorphous. Because of intramolecular hydrogen bonding between the amino and dihydrofuran-2,5-dione groups and the clustering of locked $\mathrm{C}=\mathrm{O}$ groups from the POSS NPs of the MIPOSS-NHBu units, the intramolecular motion of the polymer chain was restricted, thereby resulting in stronger light emission than that from the MIPOSS unit. These novel luminescent copolymers displayed good selectivity responses for the detection of metal ions.

Supplementary Materials: The following are available online at www.mdpi.com/2073-4360/9/3/103/s1. Table S1: Quantum yield (\%) of MIPOSS-NHBu, and poly(S-alt-MIPOSS-Br). Figure S1: 1H NMR spectrum of MIPOSS-2Br. Figure S2: 13C NMR spectrum of MIPOSS-2Br. Figure S3: FTIR spectra of (a) poly(S-alt-MIPOSS-NHBu), (b) poly(AS-alt-MIPOSS-NHBu), and (c) poly(HS-alt-MIPOSS-NHBu). Figure S4: GPC analyses of the alternating copolymers (a) poly(S-alt-MIPOSS-Br), (b) poly(AS-alt-MIPOSS-Br), (c) poly(S-alt-MIPOSS-NHBu), and (d) poly(AS-alt-MIPOSS-NHBu). Figure S5: DSC thermograms of (a) MIPOSS, (b) MIPOSS-2Br, (c) MIPOSS-Br, and (d) MIPOSS-NHBu. Figure S6: TGA analyses of the alternating copolymers poly(S-alt-MIPOSS-Br) and poly(S-alt-MIPOSS-NHBu). Figure S7: WAXD patterns of the monomer MIPOSS. Figure S8: UV-vis spectra of the monomers (a) MIPOSS, (b) MIPOSS-2Br, (c) MIPOSS-Br and (d) MIPOSS-NHBu in DCM solution (10-4 M). Figure S9: Fluorescence spectra of the monomer MIPOSS-NHBu in THF solution at concentrations from 10-5 to 10-2 M (excitation: $330 \mathrm{~nm}$ ). Figure S10: UV-vis spectra of the alternating copolymers (a) poly(S-alt-MIPOSS-Br), (b) poly(S-alt-MIPOSS-NHBu), (c) poly(AS-alt-MIPOSS-Br), and (d) poly(AS-alt-MIPOSS-NHBu) in DCM solution (10-4 M). Figure S11: Fluorescence spectra (excitation: $330 \mathrm{~nm}$ ) of (A) poly(S-alt-MIPOSS-NHBu) and (B) poly(AS-alt-MIPOSS-NHBu) in THF/H2O at various ratios, at a concentration of 10-4 M. Figure S12: DLS analysis of the monomer MIPOSS-NHBu in THF/H2O at various ratios, at a concentration of 10-4 M. Figure S13: DLS analysis of (A) poly(S-alt-MIPOSS-NHBu) and (B) poly(AS-alt-MIPOSS-NHBu) in THF/H2O at various ratios, at a concentration of 10-4 M.

Acknowledgments: This study was supported financially by the Ministry of Science and Technology, Taiwan under contracts MOST103-2221-E-110-079-MY3 and MOST 105-2221-E-110-092-MY3.

Author Contributions: Mohamed Gamal Mohamed, Yu-Ru Jheng, and Shu-Ling Yeh contributed to the synthesis of POSS copolymers. Tao Chen, and Shiao-Wei Kuo coordinated the study, interpreted the results, and wrote the paper.

Conflicts of Interest: The authors declare no conflict of interest.

\section{References}

1. Hawker, C.J.; Wooley, K.L. The convergence of synthetic organic and polymer chemistries. Science 2005, 309, 1200-1205. [CrossRef] [PubMed]

2. Borisov, S.M.; Wolfbies, O.S. Optical Biosensors. Chem. Rev. 2008, 108, 423-461. [CrossRef] [PubMed]

3. Gather, M.C.; Kohnen, A.; Meerholz, K. White organic light-emitting diodes. Adv. Mater. 2011, 23, $233-248$. [CrossRef] [PubMed]

4. Kim, H.N.; Guo, Z.; Zhu, W.; Yoon, J.; Tian, H. Recent progress on polymer-based fluorescent and colorimetric chemosensors. Chem. Soc. Rev. 2011, 40, 79-93. [CrossRef] [PubMed]

5. Mattoussi, H.; Palui, G.; Na, H.B. Luminescent quantum dots as platforms for probing in vitro and in vivo biological processes. Adv. Drug Deliv. Rev. 2012, 64, 138-166. [CrossRef] [PubMed]

6. Wang, H.; Zhao, E.G.; Lam, J.W.; Tang, B.Z. AIE luminogens: Emission brightened by aggregation. Mater. Today 2015, 18, 365-377. [CrossRef]

7. Wu, J.; Liu, W.; Ge, J.; Zhang, H.; Wang, P. New sensing mechanisms for design of fluorescent chemosensors emerging in recent years. Chem. Soc. Rev. 2011, 40, 3483-3495. [CrossRef] [PubMed]

8. Kwok, R.T.; Leung, C.W.; Lam, J.W.; Tang, B.Z. Biosensing by luminogens with aggregation-induced emission characteristics. Chem. Soc. Rev. 2015, 44, 4228-4238. [CrossRef] [PubMed]

9. Qin, A.J.; Lam, J.W.Y.; Tang, B.Z. Luminogenic polymers with aggregation-induced emission characteristics. Prog. Polym. Sci. 2012, 37, 182-209. [CrossRef] 
10. Liu, B.; Dan, T.; Bazan, G.C. Collective response from a cationic tetrahedral fluorene for label-free DNA detection. Adv. Funct. Mater. 2007, 17, 2432-2438. [CrossRef]

11. Shimizu, M.; Takeda, Y.; Higashi, M.; Hiyama, T. 1,4-Bis(alkenyl)-2,5-dipiperidinobenzenes: Minimal fluorophores exhibiting highly efficient emission in the solid state. Angew. Chem. 2009, 48, 3707-3710. [CrossRef]

12. Gan, S.; Luo, W.; He, B.; Chen, L.; Nie, H.; Hu, R.; Qin, A.; Zhao, Z.; Tang, B.Z. Integration of aggregation-induced emission and delayed fluorescence into electronic donor-acceptor conjugates. J. Mater. Chem. C 2016, 4, 3705-3708. [CrossRef]

13. Zhao, E.; Li, H.; Ling, J.; Wu, H.; Wang, J.; Zhang, S.; Lam, J.W.Y.; Sun, J.Z.; Qin, A.; Tang, B.Z. Structure-dependent emission of polytriazoles. Polym. Chem. 2014, 5, 2301-2308. [CrossRef]

14. Wang, M.; Zhang, G.; Zhang, D.; Zhu, D.; Tang, B.Z. Fluorescent bio/chemosensors based on silole and tetraphenylethene luminogens with aggregation-induced emission feature. J. Mater. Chem. 2010, 20, 1858-1867. [CrossRef]

15. Mohamed, M.G.; Lu, F.H.; Hong, J.L.; Kuo, S.W. Strong emission of 2, 4, 6-triphenylpyridine-functionalized polytyrosine and hydrogen-bonding interactions with poly (4-vinylpyridine). Polym. Chem. 2015, 6, 6340-6350. [CrossRef]

16. Toal, J.; Jones, K.A.; Magde, D.; Trogler, W.C. Luminescent silole nanoparticles as chemoselective sensors for Cr (VI). J. Am. Chem. Soc. 2005, 127, 11661-11665. [CrossRef] [PubMed]

17. Wang, M.; Zhang, D.; Zhang, G.; Tang, Y.; Wang, S.; Zhu, D. Fluorescence turn-on detection of DNA and label-free fluorescence nuclease assay based on the aggregation-induced emission of silole. Anal. Chem. 2008, 80, 6443-6448. [CrossRef] [PubMed]

18. Ding, D.; Liu, J.; Feng, G.; Li, K.; Hu, Y.; Liu, B. Bright far-red/near-infrared conjugated polymer nanoparticles for in vivo bioimaging. Small 2013, 9, 3093-3102. [CrossRef] [PubMed]

19. Luo, J.D.; Xie, Z.L.; Lam, J.W.Y.; Cheng, L.; Chen, H.Y.; Qiu, C.F.; Zhu, D.B.; Tang, B.Z. Aggregation-induced emission of 1-methyl-1,2,3,4,5-pentaphenylsilole. Chem. Commun. 2001, 1740-1741. [CrossRef]

20. Gong, Y.; Zhao, L.; Peng, Q.; Fan, D.; Yuan, W.Z.; Zhang, Y.; Tang, B.Z. Crystallization-induced dual emission from metal-and heavy atom-free aromatic acids and esters. Chem. Sci. 2015, 6, 4438-4444. [CrossRef]

21. Bao, S.; Wu, Q.; Qin, W.; Yu, Q.; Wang, J.; Liang, G.; Tang, B.Z. Sensitive and reliable detection of glass transition of polymers by fluorescent probes based on AIE luminogens. Polym. Chem. 2015, 6, 3537-3542. [CrossRef]

22. Lou, X.; Zhao, Z.; Hong, Y.; Dong, C.; Xu, X.; Jia, Y.; Xia, F.; Tang, B.Z. A new turn-on chemosensor for bio-thiols based on the nanoaggregates of a tetraphenylethene-coumarin fluorophore. Nanoscale 2014, 6, 14691-14696. [CrossRef] [PubMed]

23. An, B.K.; Kwon, S.K.; Jung, S.D.; Park, S.Y. Enhanced emission and its switching in fluorescent organic nanoparticles. J. Am. Chem. Soc. 2002, 124, 14410-14415. [CrossRef] [PubMed]

24. Xu, Y.; Chen, L.; Guo, Z.; Nagai, A.; Jiang, D. Light-emitting conjugated polymers with microporous network architecture: Interweaving scaffold promotes electronic conjugation, facilitates exciton migration, and improves luminescence. J. Am. Chem. Soc. 2011, 133, 17622-17625. [CrossRef] [PubMed]

25. Ooyama, Y.; Yoshikawa, S.; Watanabe, S.; Yoshida, K. Molecular design of novel non-planar heteropolycyclic fluorophores with bulky substituents: Convenient synthesis and solid-state fluorescence characterization. Org. Biomol. Chem. 2006, 4, 3406-3409. [CrossRef] [PubMed]

26. Lin, L.Y.; Huang, P.C.; Yang, D.J.; Gao, J.Y.; Hong, J.L. Influence of the secondary structure on the AIE-related emission behavior of an amphiphilic polypeptide containing a hydrophobic fluorescent terminal and hydrophilic pendant groups. Polym. Chem. 2016, 7, 153-163. [CrossRef]

27. Hsiao, T.S.; Deng, S.L.; Shih, K.Y.; Hong, J.L. Crystallization-enhanced emission through hydrogen-bond interactions in blends containing hydroxyl-functionalized azine and poly (4-vinyl pyridine). J. Mater. Chem. C 2014, 2, 4828-4834. [CrossRef]

28. Shigemitsu, Y.; Mutai, T.; Houjou, H.; Araki, K. Excited-state intramolecular proton transfer (ESIPT) emission of hydroxyphenylimidazopyridine: Computational study on enhanced and polymorph-dependent luminescence in the solid state. J. Phys. Chem. A 2012, 116, 12041-12048. [CrossRef] [PubMed]

29. Qin, X.; Li, H.; Lam, J.W.Y.; Yuan, X.; Wei, J.; Tang, B.Z.; Zhang, H. Graphene oxide as a novel nanoplatform for enhancement of aggregation-induced emission of silole fluorophores. Adv. Mater. 2012, 24, 4191-4195. 
30. Fang, H.H.; Chen, Q.D.; Yang, J.; Xia, H.; Gao, B.R.; Feng, J.; Ma, Y.G.; Sun, H.B. Two-photon pumped amplified spontaneous emission from cyano-substituted oligo( $p$-phenylenevinylene) crystals with aggregation-induced emission enhancement. J. Phys. Chem. C 2012, 114, 11958-11961. [CrossRef]

31. Mohamed, M.G.; Hsu, K.C.; Hong, J.L.; Kuo, S.W. Unexpected fluorescence from maleimide-containing polyhedral oligomeric silsesquioxanes: Nanoparticle and sequence distribution analyses of polystyrene-based alternating copolymers. Polym. Chem. 2016, 7, 135-145. [CrossRef]

32. Yu, Y.; Li, J.; Chen, S.; Hong, Y.; Ng, K.M.; Luo, K.Q.; Tang, B.Z. Thiol-reactive molecule with dual-emission-enhancement property for specific prestaining of cysteine containing proteins in SDS-PAGE. ACS. Appl. Mater. Interfaces 2013, 5, 4613-4616. [CrossRef] [PubMed]

33. Hong, Y.; Lam, J.W.Y.; Tang, B.Z. Aggregation-induced emission. Chem. Soc. Rev. 2011, 40, 5361-5388. [CrossRef] [PubMed]

34. Yan, Y.; Zheng, B.; Pan, D.; Yang, R.; Xu, Y.; Wang, L.; Yang, M. Unexpected fluorescence from polymers containing dithio/amino-succinimides. Polym. Chem. 2015, 6, 6133-6139. [CrossRef]

35. Pucci, A.; Rause, R.; Ciardelli, F. Aggregation-induced luminescence of polyisobutene succinic anhydrides and imides. Macromol. Chem. Phys. 2008, 209, 900-906. [CrossRef]

36. Zhao, E.; Lam, J.W.Y.; Meng, L.; Hong, Y.; Deng, H.; Bai, G.; Huang, X.; Hao, J.; Tang, B.Z. Poly [(maleic anhydride)-alt-(vinyl acetate)]: A pure oxygenic nonconjugated macromolecule with strong light emission and solvatochromic effect. Macromolecules 2015, 48, 64-71. [CrossRef]

37. Wu, D.; Cheung, S.; Devocelle, M.; Zhang, L.J.; Chen, Z.L.; ÓShea, D.F. Synthesis and assessment of a maleimide functionalized BF 2 azadipyrromethene near-infrared fluorochrome. Chem. Commun. 2015, 51, 16667-16670. [CrossRef] [PubMed]

38. Kuo, S.W.; Chang, F.C. POSS related polymer nanocomposites. Prog. Polym. Sci. 2011, 36, $1649-1696$. [CrossRef]

39. Scott, D.W. Thermal rearrangement of branched-chain methylpolysiloxanes. J. Am. Chem. Soc. 1946, 68, 356-358. [CrossRef]

40. Li, G.; Wang, L.; Ni, H.; Pittman, C.U. Polyhedral oligomeric silsesquioxane (POSS) polymers and copolymers: A review. J. Inorg. Organomet. Polym. 2002, 11, 123-154. [CrossRef]

41. Laine, R.M.; Roll, M.F. Polyhedral phenylsilsesquioxanes. Macromolecules 2011, 44, 1073-1109. [CrossRef]

42. Marcolli, C.; Calzaferri, G. Monosubstituted octasilasesquioxanes. Appl. Organomet. Chem. 1999, 13, $213-226$. [CrossRef]

43. Zhang, W.A.; Muller, A.H.E. Architecture, self-assembly and properties of well-defined hybrid polymers based on polyhedral oligomeric silsequioxane (POSS). Prog. Polym. Sci. 2013, 38, 1121-1162. [CrossRef]

44. Mark, E.J. Some interesting things about polysiloxanes. Acc. Chem. Res. 2004, 37, 946-953. [CrossRef] [PubMed]

45. Wu, J.; Mather, P.T. POSS polymers: Physical properties and biomaterials applications. Polym. Rev. 2009, 49, 25-63. [CrossRef]

46. Li, Y.W.; Zhang, W.B.; Hsieh, I.F.; Zhang, G.L.; Cao, Y.; Li, X.P.; Wesdemiotis, C.; Lotz, B.; Xiong, H.; Cheng, S.Z.D. Breaking symmetry toward nonspherical janus particles based on polyhedral oligomeric silsesquioxanes: Molecular design, "click" synthesis, and hierarchical structure. J. Am. Chem. Soc. 2011, 133, 10712-10715. [CrossRef] [PubMed]

47. Baney, R.H.; Itoh, M.; Sakakibara, A.; Suzuki, T. Silsesquioxanes. Chem. Rev. 1995, 95, 1409-1430. [CrossRef]

48. Laine, R.M. Nanobuilding blocks based on the $\left[\mathrm{OSiO}_{1.5}\right]_{\mathrm{x}}(\mathrm{x}=6,8,10)$ octasilsesquioxanes. J. Mater. Chem. 2005, 15, 3725-3744. [CrossRef]

49. Cordes, D.B.; Lickiss, P.D.; Rataboul, F. Recent developments in the chemistry of cubic polyhedral oligosilsesquioxanes. Chem. Rev. 2010, 110, 2081-2173. [CrossRef] [PubMed]

50. Yang, Y.Y.; Wang, X.; Hu, Y.; Hu, H.; Wu, D.C.; Yu, F.J. Bioreducible POSS-cored star-shaped polycation for efficient gene delivery. ACS. Appl. Mater. Interface 2014, 6, 1044-1052. [CrossRef] [PubMed]

51. Yu, X.; Zhong, S.; Li, X.; Tu, Y.; Yang, S.; Van Horn, R.M.; Ni, C.; Pochan, D.J.; Wesdemiotis, C.; Zhang, W.B.; et al. A giant surfactant of polystyrene-(carboxylic acid-functionalized polyhedral oligomeric silsesquioxane) amphiphile with highly stretched polystyrene tails in micellar assemblies. J. Am. Chem. Soc. 2010, 132, 16741-16744. [CrossRef] [PubMed] 
52. Zhang, W.; Wang, S.; Kong, J. Hemi-telechelic and telechelic organic/inorganic poly(ethylene oxide) hybrids based on polyhedral oligmeric silsesquioxanes (POSSs): Synthesis, morphology and self-assembly. React. Funct. Polym. 2012, 72, 580-587. [CrossRef]

53. Kuo, S.W.; Lee, H.F.; Huang, W.J.; Jeong, K.U.; Chang, F.C. Solid state and solution self-assembly of helical polypeptides tethered to polyhedral oligomeric silsesquioxanes. Macromolecules 2009, 42, 1619-1626. [CrossRef]

54. Ishida, Y.; Hirai, T.; Goseki, R.; Tokita, M.; Kakimoto, M.A.; Hayakawa, T. Synthesis and self-assembly of thermotropic block copolymer with long alkyl tethered cage silsesquioxane in the side chain. J. Polym. Sci. Part A Polym. Chem. 2011, 49, 2653-2664. [CrossRef]

55. Hirai, T.; Leolukman, M.; Hayakawa, T.; Kakimoto, M.; Gopalam, P. Hierarchical nanostructures of organosilicate nanosheets within self-organized block copolymer films. Macromolecules 2008, 41, 4558-4560. [CrossRef]

56. Zhang, Z.; Hong, L.; Gao, Y.; Zhang, W. One-pot synthesis of POSS-containing alternating copolymers by RAFT polymerization and their microphase-separated nanostructures. Polym. Chem. 2014, 5, 4534-4541. [CrossRef]

57. Yan, J.J.; Wang, D.; Wu, D.C.; You, Y.Z. Synthesis of sequence-ordered polymers via sequential addition of monomers in one pot. Chem. Commun. 2013, 49, 6057-6059. [CrossRef] [PubMed]

58. Chiou, C.W.; Lin, Y.C.; Hayakawa, T.; Kuo, S.W. Hydrogen bond interactions mediate hierarchical self-assembly of POSS-containing block copolymers blended with phenolic resin. Macromolecules 2014, 47, 8709-8721. [CrossRef]

(c) 2017 by the authors. Licensee MDPI, Basel, Switzerland. This article is an open access article distributed under the terms and conditions of the Creative Commons Attribution (CC BY) license (http:/ / creativecommons.org/licenses/by/4.0/). 